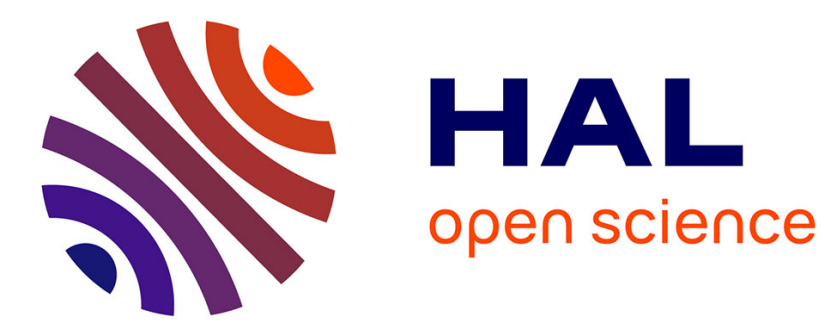

\title{
The Impact of Debtor-Friendly Reforms on the Performance of a Reorganization Procedure
}

Timothy C.G. Fisher, Jocelyn Martel

\section{To cite this version:}

Timothy C.G. Fisher, Jocelyn Martel. The Impact of Debtor-Friendly Reforms on the Performance of a Reorganization Procedure. 2012. hal-00707359

\section{HAL Id: hal-00707359 \\ https://hal.science/hal-00707359}

Preprint submitted on 12 Jun 2012

HAL is a multi-disciplinary open access archive for the deposit and dissemination of scientific research documents, whether they are published or not. The documents may come from teaching and research institutions in France or abroad, or from public or private research centers.
L'archive ouverte pluridisciplinaire $\mathbf{H A L}$, est destinée au dépôt et à la diffusion de documents scientifiques de niveau recherche, publiés ou non, émanant des établissements d'enseignement et de recherche français ou étrangers, des laboratoires publics ou privés. 


\title{
The Impact of Debtor-Friendly Reforms on the Performance of a Reorganization Procedure
}

\author{
Timothy C.G. Fisher \\ School of Economics \\ University of Sydney \\ NSW 2006 \\ Australia \\ T: +61293515724 \\ F: +61293514341 \\ E: T.Fisher@sydney.edu.au \\ Jocelyn Martel \\ Department of Finance \\ ESSEC Business School \\ \& THEMA \\ 95021 Cergy-Pontoise Cedex \\ France \\ T: +31 134934430 \\ F: +31134934030 \\ E: martel@essec.fr
}

January 3, 2012 


\title{
The Impact of Debtor-Friendly Reforms on the Performance of a Reorganization Procedure
}

\author{
January 3, 2012
}

\begin{abstract}
Recent changes to Canadian bankruptcy law provide a natural experiment that we use to evaluate the impact of the international trend towards Chapter 11-style reorganization laws. Comparing random samples of reorganizing firms from before and after the law change show that changes to the law are associated with higher incentives for debtors to buy time prior to filing a proposal, a longer time in reorganization and a higher bankruptcy costs to assets ratio. The primary objective of the reform to attract more firms in reorganization has been met. The data also show that the system now attracts smaller and weaker firms although this has had very little impact on the acceptance rate and completion rate of reorganization plans.
\end{abstract}

Keywords: financial reorganization, bankruptcy law, economic efficiency.

JEL classification: G33, L11. 


\section{Introduction}

While economic systems have converged rapidly in the last 60 years, national financial regulations have changed much more slowly. Despite similarities in the way economies operate, there are important differences in bankruptcy laws across countries. In their seminal paper, LaPorta \& al. (1998) examine creditors' rights in bankruptcy and reorganization, and derive an aggregate index of four variables related to the functioning of the law. Using the index, they rank countries according to the level of protection offered to creditors and conclude that U.S. bankruptcy law offers the lowest level of creditors' rights while U.K. law offers the highest. ${ }^{1}$ This ranking is consistent with the view that the U.S. Bankruptcy Code is oriented towards rescuing insolvent businesses and is considered to be 'soft' or 'debtor-friendly,' favoring incumbent management. The U.K. Administrative Receivership system, in contrast, is considered to be 'tough' or 'creditor-friendly,' favoring the retrieval of secured loans over survival of the business. This raises the question: is there such a thing as an optimal bankruptcy law in a market economy? ${ }^{2}$ If so, what form would that law take? Would it be creditor-friendly or debtorfriendly? Would it incorporate a process like Chapter 11? And what happens when legislation changes a creditor-friendly law into a debtor-friendly law?

In evaluating bankruptcy law, an obvious starting point is to consider what the optimal law would look like. Hart (1995) identifies two desirable goals for bankruptcy law: ex post efficiency and ex ante efficiency. An ex post efficient law maximizes the total value of a bankrupt firm. It is desirable because, other things equal, if a law can be modified to deliver higher total value following bankruptcy, then, provided ex ante efficiency is satisfied, ev-

\footnotetext{
${ }^{1}$ The index is constructed in terms of the rights of senior secured creditors and may not reflect the rights of other creditors. Interestingly, the authors conclude that the Canadian law, which has its origins in the British insolvency law, offers the same level of creditors' rights as U.S. law.

${ }^{2}$ Hart(2000) expresses doubt in the possibility of a 'one size fits all' bankruptcy legislation. Nonetheless, the spirit of the World Bank's Doing Business reports (2004, 2005, 2006, 2007) approach, which encourages specific kinds of reform to business laws, seems to be precisely that. Also see Berkovitch and Israel $(1998,1999)$.
} 
erybody will be better off. An ex ante efficient law maximizes the total value of a firm before the onset of bankruptcy, which is achieved primarily through its affect on management behavior. Measures of ex ante efficiency are hard to implement because the predicted sources of ex ante effects on managerial behavior are many and varied. ${ }^{3}$ Given the difficulty with measuring ex ante efficiency, much of the empirical work on bankruptcy focuses on ex post efficiency.

A first measure of the ex post efficiency of a reorganization procedure is related to the ability of firms to emerge with a new capital structure. Given the sequential nature of procedures in the U.S. and Canada, emergence from reorganization requires two conditions. First, the firm must receive confirmation by the creditors and the court for its proposal. Second, conditional upon confirmation, it must respect all the conditions, in particular regarding the payments to creditors, specified in the proposal. Firms that satisfy both conditions are defined to be "successful" and exit the reorganization procedure with a new capital structure.

A second measure of ex-post efficiency is the ability to find a solution to financial distress at the lowest possible cost. Bankruptcy costs have two components: direct costs, which represent the administrative costs of the process, and indirect costs, which comprise the negative effects on a firm's reputation in product and capital markets as well as the opportunity costs associated with the loss of key personnel and management time.

A third important aspect in reorganization is the extent to which the absolute priority (AP) rule is enforced. AP requires that senior creditors are fully paid (i.e., retain control of their claims) before junior creditors and stockholders receive any payment. It is a feature of almost all existing bankruptcy laws including Chapter 11. Directly related to AP is the debt recovery rate of different classes of creditors. As pointed out by Hotchkiss

\footnotetext{
${ }^{3}$ Models have been developed showing that bankruptcy may reduce moral hazard on the part of the manager, encourage investments in firm-specific human capital, discourage excessive risk-taking, and so on. See Hotchkiss and al. (2008) for a literature review of financial distress.
} 
\& al. (2008), debt recovery rates are affected by the extent to which AP is violated and by the magnitude of direct and indirect bankruptcy costs. They also provide an indication of the ability of creditors to recover their claims.

Empirical studies of bankruptcy focus on these three aspects of ex post efficiency. While the bulk of this literature examines the U.S. Bankruptcy Code, systems in Canada, the U.K. and France have also been studied. The U.S. studies are, on the whole, highly critical of Chapter 11. The proportion of firms emerging successfully from Chapter 11 is very low, especially in the case of small firms [LoPucki (1983), White (1984), Flynn (1989), JensenConklin (1992), Altman (1993b), Baird (1993), Bris \& al. (2006), Denis \& Rodgers (2007) and Morrison (2007)], the bargaining power of incumbent management is very high, fundamental efficiency properties, such as AP, are systematically violated [Franks and Torous $(1989,1994)$, Eberhart \& al. (1990), Weiss (1990), LoPucki and Withford (1990), Betker (1995), Bris \& al. (2006) and Bharath (2007)], while the process is time-consuming, litigious, has high direct costs [Bermant \& al. (1991), LoPucki \& Withford (1991), LoPucki (1993), Lawless \& Ferris (2000), Bris \& al. (2006)] and high indirect costs as measured by the time a firm spends under bankruptcy protection [Altman (1984), Flynn (1989), Gilson \& al. (1990), Weiss (1990), Lopucki and Withford (1991), Jensen-Conklin (1992), Daigle and Maloney (1994), Franks and Torous (1994), Bris \& al. (2006)]. Studies of direct bankruptcy costs for large cases show that bankruptcy costs can be relatively low [White (1984), Altman (1984), Gilson \& al. (1990), Betker (1997), Luben (2000) and LoPucki \& Doherty (2004)]. ${ }^{4}$

A recent criticism of Chapter 11 [Baird \& Rasmussen $(2002,2003)$ and Morrison (2007)], is that its original objective of preserving going-concern value is no longer being attained. Claiming that use of Chapter 11 is steadily declining, Baird \& Rasmussen (2002) assert: "We have to be realistic about the types of firms that are being saved. We have electrical sub-contractors, mom-and-pop restaurants, and retailers with high mark-ups. There are few employees and the turnover of employees in these firms tends to be high. The

\footnotetext{
${ }^{4} \mathrm{By}$ no means is all the literature critical of Chapter 11 - see, for example, Mooradian (1994), Kahl (2002). and Morrison (2007). Also see Hotchkiss \& al. (2008).
} 
principal value of preserving such small firms is that it allows their owners to continue to enjoy the psychic benefit of running their own business. The costs fall disproportionately on non-adjusting creditors." On the other hand, LoPucki (2003) claims not only that use of Chapter 11 is booming but also that it remains the foremost vehicle for firms to reorganize their debt and save their going-concern value and the valuable relationships among people in the firm. Yet another view, put forward by Skeel (2003) and Bharath \& al. (2007) is that while it is debtor-friendly in nature, Chapter 11 has gradually become creditor-friendly and that creditors now dominate the reorganization process.

Reinforcing the U.S. studies, comparative evidence from bankruptcies in other countries suggests Chapter 11 under-performs in a number of key areas. ${ }^{5}$ Paradoxically, there is an international trend towards adopting Chapter 11-style reorganization laws. In the last 20 years, the U.K., Canada, Australia, France, Germany, Finland, Norway, and Sweden, have all adopted procedures similar to Chapter 11. How can it be that lawmakers in other countries are so enthusiastic about adopting the features of a law that apparently performs poorly?

One possibility is that the evidence on Chapter 11 is not convincing on several fronts. First, empirical studies of Chapter 11 lack a benchmark because the law has essentially been unchanged since $1978 .{ }^{6}$ Second, international comparisons suffer from an identification problem. Differences between firms in Chapter 11 and bankrupt firms in other countries may be due not to differences in bankruptcy law but to differences in secured lending practices, non-bankruptcy financial law, market structure, or other factors that could influence bankruptcy outcomes. Third, samples of firms in Chapter 11 are typically not representative. Altman (1993a) notes that $99.5 \%$ of all Chapter 11 filings are by small, privately held firms. Most studies of Chap-

\footnotetext{
${ }^{5}$ For instance, see Fisher \& Martel $(1995,1999,2005)$ for Canadian evidence.

${ }^{6}$ According to Lawless (2007), the recent changes introduced by The Bankruptcy Abuse Prevention and Consumer Protection Act of 2005 could have important implications for small businesses filing for bankruptcy.
} 
ter 11 bankruptcies, however, focus on large, publicly-traded companies. ${ }^{7}$ Thus, with the exception of Warren \& Westbrook (2000), Bris \& al.(2006) and Morrison (2007), there is little extant evidence on 'ordinary corporate bankruptcies' in the U.S.

Confronting the inconsistency between international bankruptcy law reform with the received evidence on Chapter 11, the case of Canada is potentially highly informative. Canadian bankruptcy law was reformed in 1992 with the intention of making it more debtor-friendly and more similar to Chapter 11. In this paper, we compare two groups of firms. The first group of 393 firms attempted reorganization during 1977-88 under the Bankruptcy Act (BA) of 1949. The second group of 640 firms attempted reorganization during 1993-2007 under the Bankruptcy and Insolvency Act (BIA), which replaced the BA on December 1, 1992. This data set is the largest ever assembled on firms in reorganization for a given bankruptcy system. By comparing these two groups, we are able to assess the impact of the new, debtor-friendly bankruptcy law.

Compared with previous empirical work, our sample design produces an explicit benchmark: the group of firms that reorganized under the old law. It also allows us to control more comprehensively for potential influences on the behavior of reorganizing firms, thereby addressing the identification problem. In particular, because the two samples of firms are taken from adjacent time periods in the same country, the economic, financial, and legal factors outside of bankruptcy law that could influence the behavior of reorganizing firms are effectively held constant. Lastly, because both samples are randomly selected from their respective time periods, they are representative of reorganizing firms in Canada before and after the introduction of the new law. In short, the new law provides a natural experiment that may be used to measure the impact of moving towards a debtor-friendly bankruptcy law similar to Chapter 11. As such, our results should provide insight not only into the impact of bankruptcy laws recently introduced in many countries but also into the inner workings of Chapter 11.

\footnotetext{
${ }^{7}$ For example, see Franks and Torous (1989, 1994), Betker (1995), Hotchkiss (1995), Weiss and Wruck (1998), and more recently, Denis and Rodgers (2007).
} 
We evaluate the impact of the new law in terms of the individual characteristics of firms in reorganization and the outcome of the different stages in the reorganization process: the likelihood that debtors file a holding proposal or a notice of intention (NOI), that creditors' confirm the reorganization plan, that a plan is successfully completed, the duration of the reorganization process, and the bankruptcy costs. We find that firms filing under the BIA are smaller and financially weaker than those filing under the BA. Under the BIA, a significant proportion of debtors file a notice of intention prior to filing a proposal. We find that filing an NOI has a negative impact on the likelihood of acceptance and completion of a plan, which suggests that creditors perceive these attempts as strategic decision from debtors to buy time. The new law has also reduced the negative impact of government claims in the whole reorganization process. Reorganization takes longer under the BIA, suggesting that indirect bankruptcy costs have increased. The analysis also shows that under the new law total bankruptcy costs capture a larger proportion of the debtors' assets.

The paper is organized as follows. Section 2 describes the changes to Canadian bankruptcy law introduced with the BIA. Section 3 discusses our data, which comprises randomly-selected, firm-level data from before and after the changes to the law. Section 4 discusses our empirical approach. We examine whether the new law had an impact on firm characteristics, if assetvalues are maximized, the degree to which reorganization ends in failure, and creditors' recovery rates. To evaluate costs, we examine direct (administrative) bankruptcy costs and the duration of reorganization as an indicator of indirect bankruptcy costs. Results are discussed in section 5. In section 6, we argue that the primary objective of the reform was reached. Between 1992 and 2007, the number of commercial proposals has risen by a factor of twelve and the ratio of proposals to bankruptcy (liquidation) for businesses has risen by a factor of twenty-five. The analysis also suggests that the major source of firms filing under the BIA is firms that would have liquidated under the previous regime, i.e., firms in left-hand tail of the distribution of financially distressed firms. Interestingly, this change in the population of firms in reorganization has not affected the acceptance and completion rate 
of proposals. However, the reorganization process is now capturing a larger share of the debtors' assets. In section 7, we conclude.

\section{Canadian Bankruptcy Law}

Canadian bankruptcy law has its origins in British insolvency law. Over the last century or so Canadian law has been modified to the extent that it has become more similar to American bankruptcy law. While fundamental doctrines of American law - such as debtor-in-possession, cram down, and the ability of the debtor to reject contracts - are not present in Canadian law, the overarching goal of both systems today is to reorganize viable businesses while minimizing losses to all parties [LoPucki \& Triantis (1994), Triantis (1996)]. The convergence of Canadian and American bankruptcy law reaches its apogee with the BIA in 1992. Figure 1 offers a complete picture of the Canadian reorganization process under the new Act. ${ }^{8}$ The BIA contained five major changes from the BA.

\section{Voting criteria}

Under both the BA and the BIA, the fate of a reorganization plan (or 'proposal') is determined at a meeting of creditors. A plan was deemed to be accepted under the BA if a majority of the unsecured creditors at the meeting voted in favor of the plan and the claims of those in favor represented at least three-quarters of the total claims of creditors at the meeting $[\S 2,54]$. Under the BIA, the majority by number rule remains while the claims of those voting in favor of the plan only have to represent two-thirds of the total claims of creditors at the meeting in order for a plan to be accepted [§54(1)]. The new law thus reduces the veto power of large creditors. While a veto required more than $25 \%$ of total claims under the BA, it requires more than $33 \frac{1}{3} \%$ of

\footnotetext{
${ }^{8}$ The BA did not provide for the filing of a notice of intention but debtors could file a "holding proposal" which aimed at staying the procedures of creditors until the filing of a final plan.
} 
total claims under the BIA. The new criterion brings the voting rules under Canadian law into line with those in Chapter 11.

\section{Stay of proceedings}

A stay of proceedings on all unsecured claims was triggered automatically when a firm filed for reorganization under the BA [§69(1)]. The stay elapsed either when the plan has been refused or the trustee has been discharged. Under the BIA, both secured and unsecured claims are stayed for 30 days when the debtor issues a 'notice of intention' (NOI) to file a proposal. After 30 days, the debtor may either present a plan to its creditors or apply to the court to extend the stay (in 45-day segments) up to a maximum of five months $[\S 50.4(9), 69(1)]$. If granted, the extended stay applies to all creditors. Once the proposal is submitted to creditors, a further 21 days elapses before the creditors meeting $[\S 51(1)]$. Debtors may extend the 21-day period with the permission of creditors [§52]. Thus, the BIA not only extends the stay of proceedings to secured claims but also significantly increases the length of the stay. The stay of proceedings under the BIA is similar to the exclusivity period granted to management under Chapter 11.

\section{Secured creditors}

The actions of secured creditors were not restricted by the BA. Secured creditors could demand immediate repayment of overdue loans or petition for a debtor in default to be placed into receivership, effectively giving secured creditors the power to terminate plans. The power of secured creditors was muted by the BIA. As mentioned above, secured claims are stayed for a period of 30 days when a NOI is filed. Moreover, under the BIA, debtors may include secured creditors in reorganization plans [\$69.1(1)]. A secured creditor voting in favor of a plan is bound by its terms. A secured creditors voting against a plan is not so bound and may claim its security in the event 
of default $[\S 69.1(6)] .{ }^{9}$ A secured creditor that is not included in a plan may, in the event of default, claim its security 10 days after sending a notice to the debtor subject to the expiration of the NOI $[\S 244(2)(3)]$. The treatment of secured creditors in the BIA is now closer to the provisions of Chapter 11.

\section{Crown priority}

Federal and provincial governments (Crown) were given preferred status under the BA, placing their claims ahead of other unsecured creditors [§60(1), 136(1)]. Crown claims had to be paid immediately and in full as a condition for the bankruptcy court's confirmation of a plan. Under the BIA, Crown priority is restricted to 'source deductions' - amounts collected by the debtor on behalf of governments, such as income taxes, Canada Pension Plan contributions, and Employment Insurance premiums [§60(1.1))]. All other Crown claims (e.g., corporate income tax, sales tax) are classified as unsecured claims $[\S 136(1)]$. Debtors have up to six months to repay Crown source deductions under the new law $[\S 60(1.1)]$. The new treatment of Crown claims is closer to Chapter 11, which permits a reduction in government claims and the possibility of repaying them over a period of up to six years.

\section{Employee claims}

Under the BA, employee claims were fourth on the list of preferred claims behind funeral expenses, administration costs (including trustee fees), and a filing levy charged by the Superintendent of Bankruptcy. Each employee claim for wages or vacation pay up to $\$ 500$ or expenses up to $\$ 300$, backdated up to 3 months prior to filing, ranked as a preferred claim; additional amounts ranked as ordinary claims [\$136(1)]. Each employee with an ordinary claim was entitled to vote on a reorganization proposal at the meeting of creditors. Under the BIA, the maximum amount for an employee preferred claim was raised to $\$ 2,000$ for wages or vacation pay, $\$ 1,000$ for expenses, backdated up

\footnotetext{
${ }^{9}$ Note that the plan does not necessarily stop if a secured creditor votes against it. Each secured creditor's vote really reflects a decision whether to opt in the plan.
} 
to 6 months prior to filing [\$136(1)]. Under the new law, a reorganizing firm must repay employee preferred claims immediately and in full in order for the bankruptcy court's confirmation $[\S 60(1.3)]$. Under the BIA, employees are permitted to vote on a reorganization plan only if they have unsecured claims against the firm, i.e., if their wage (expense) claims exceed the $\$ 2,000$ $(\$ 1,000)$ limit. The BIA thus aligns employee rights in bankruptcy with those in Chapter 11.

Because they are consistent with the stated policy objective of encouraging reorganization, most of the changes brought in with the BIA would appear to be debtor-friendly. However, the effect of the BIA depends on how the changes are perceived by debtors and creditors. The relaxed voting criterion would be expected to increase the acceptance rate of plans if the new system attracts the same population of firms. However, it is possible that the acceptance rate will decrease if creditors perceive that firms filing for reorganization under the BIA are weaker. Lengthening the stay of proceedings by introducing the NOI should stimulate the use of reorganization by granting debtors more time to sort out their affairs. However, the NOI could have opposing effects on the process. On the one hand, it could increase the probability of acceptance if creditors believe that debtors are using the extra time to prepare a workable reorganization plan. On the other hand, it could decrease the probability of acceptance if creditors perceive that debtors are using the procedure simply to buy time. The stay of proceedings on secured creditors and the possibility of including them in a plan should reduce the pressure on debtors and make it more likely that a plan gets accepted. Removing preferential treatment and extending the time for repayment of (most) Crown claims should improve cash-flow under reorganization, stimulate more plans and improve the chance that plans are accepted by creditors. Finally, raising the amount of employee income that ranks as a preferred claim with immediate repayment upon court approval of the plan clearly works against reorganization since it exacerbates cash-flow difficulties faced by debtors at the time of reorganization. Furthermore, if employees tend to favor reorganization, on average, then preventing them from voting on plans could result in acceptance of fewer plans. Ultimately, the effect of 
the change in bankruptcy legislation is an empirical matter, which of course is the subject of this paper. ${ }^{10}$

\section{Data Analysis}

The data were collected directly from documents filed in bankruptcy courts by insolvent firms in Montreal and Toronto. The BA sample comprises data on 393 firms that filed between 1977 and 1988 (before the reform) and the BIA sample comprises data on 640 firms that filed between December 1992 and the end of 2007 (after the reform). Both samples were chosen randomly from the population of firms filing for reorganization in each time period. ${ }^{11}$ Data were collected manually by the authors from documents stored in archives at Industry Canada, the Canadian government department that administers bankruptcy law. The document list for each filing includes a statement of financial affairs at the time of filing and official legal papers filed by the trustee and court officials from the opening of the case to the discharge of the debtor from bankruptcy. Table 1 displays summary information on the characteristics of firms in the two samples. ${ }^{12}$

The mean value of total assets is around $\$ 3$ million for firms filing under the BA and $\$ 2.5$ million for firms filing under the BIA. ${ }^{13}$ However, the median value of assets is significantly lower, ranging from $\$ 454,000$ to $\$ 168,000$ for the BA and BIA samples respectively. Figure 2 shows the cumulative relative frequency of firm size as measured by total assets. The striking feature is that the cumulative relative frequency for the BA rises more slowly than that for the BIA. This is a first indication that firms filing under the BIA are

\footnotetext{
${ }^{10}$ Similar effects are expected on the likelihood of completion.

${ }^{11}$ Random sampling was carried out by the systematic random sampling procedure. The sample is chosen to be representative of the regional distribution of bankruptcies over time for the Montreal and Toronto offices.

${ }^{12}$ Missing values for the BA period are explained by the fact that some variables were not collected at the time.

${ }^{13}$ All dollar amounts are June 2002 Canadian dollars.
} 
significantly smaller than those filing under the BA. The mean value of total claims is around $\$ 4$ million for both periods; median values are significantly lower. Figure 3 shows that the cumulative relative frequency for total claims also rises more slowly for the BA compared with the BIA. A $t$-test and Wilcoxon rank-sum test confirms that there is statistical difference between the mean size (assets or claims) of reorganizing firms in the two samples. These values are similar to those reported in other studies on representative samples of bankrupt firms. Baldwin \& al. (1997) report median claims of $\$ 968,000$ in a sample of 1,085 Canadian bankrupt firms in $1996 .^{14}$ Bris \& al. (2006) report a median value of pre-bankruptcy assets of $\$ 1.2$ million for Chapter 11 firms: just under $50 \%$ of their firms have less than $\$ 1$ million in assets and $75 \%$ have less than $\$ 5$ million in assets. Morrison (2007) reports median assets and claims of about $\$ 115,000$ and $\$ 512,000$ respectively for a sample of firms in Chapter 11; nearly $50 \%$ of firms have less than $\$ 100,000$ in assets and $81 \%$ have less than $\$ 1$ million. $^{15}$

Returning to Table 1, the mean ratio of total assets to total claims is higher for the BA (58\%) that for the BIA (45\%) sample indicating that firms in the later sample are in weaker financial health. Ordinary unsecured claims represent more than $60 \%$ of total claims while the proportion of secured claims $(32 \%)$ is similar for both samples. ${ }^{16}$ Under the BIA, bank claims represent over $60 \%$ of secured claims. ${ }^{17}$ The mean ratio of preferred claims has dropped significantly while the mean ratio of government claims have risen by a factor of over 4 under the BIA, reflecting the removal of preferred status for the bulk of government claims. ${ }^{18}$ Interestingly, the proportion of cases with positive secured claims has fallen from $82 \%$ under the BA to $73 \%$ under the BIA. The proportion of files with government claims is relatively

\footnotetext{
${ }^{14}$ Baldwin \& al. (1997) report median claims of $\$ 813,000$ in 1992 dollars. We have converted it to June 2002 dollars.

${ }^{15}$ Warren \& Westbrook (2000) report similar findings.

${ }^{16}$ This contrasts with LaPorta \& al. (1998: 1134) which claims that much of the debt in the world is secured.

${ }^{17}$ The BA sample does not report separate data for bank claims.

${ }^{18}$ Government claims that qualify for preferred status under the BA are ranked as ordinary unsecured claims under the BIA.
} 
constant across samples at around $80 \%$. The total number of creditors is significantly lower under the BIA, with an average number of 61 creditors, compared to an average of 111 under the BA, with ordinary creditors representing over $85 \%$ of all creditors on both samples.

Table 2 offers detailed statistics on the reorganization procedure and plans filed by firms. The first striking feature is that there is no statistically significant difference between the proportion of accepted-confirmed plans under the BA $(70 \%)$ and the BIA $(77 \%)$ or the proportion of successful plans, which is $77 \%$ under the BA and $72 \%$ under the BIA. ${ }^{19}$ The unconditional completion rate of firms in reorganization is $55 \%$ in both samples. The second important point is that the total payment proposed to ordinary unsecured creditors is significantly lower for plans under the BIA. Ordinary creditors were offered, on average, 35 cents on the dollar during the BA period compared with 26 cents for the BIA period. However, it looks like the BIA has modified the distribution of payment. Figure 4 shows that the cumulative relative frequency of the payment to ordinary creditors under the BA rises more slowly than under the BIA. That is, the likelihood of a payment lower than any given threshold is higher under the BIA than under the BA. For example, the proportion of plans offering a payment less of than 25 cents on the dollar is $51 \%$ under the BA compared with $66 \%$ under the BIA.

Around $10 \%$ of payments to ordinary creditors are paid in cash; the rest are paid in installments. ${ }^{20}$ The structure of payments seems to be quite similar for both samples. Except for the proportion of payments within 1 month, which is lower for the BIA sample, the proportion of payments within 3, 6, 12 and 24 months are similar across the samples. However, the reorganization proposals filed under the BIA are structured differently. BIA plans typically have twice as many installments ( 7 for the BIA compared to 3 for the BA) and an average period for repayment of 20 months compared with 14 months for the BA. Lastly, the percentage of plans offering zero

\footnotetext{
${ }^{19}$ The Chapter 11 literature uses the term 'consummation' rather than 'completion' to refer to a successful reorganization plan.

${ }^{20}$ Any payment made within a 1 month of court approval is defined to be a cash payment. There are only 4 plans that provide for payments in equity.
} 
payment has increased by $25 \%$ under the BIA.

As already mentioned, the BIA introduced a new feature into reorganization: the notice of intention (NOI). The NOI is widely used- $65 \%$ of debtors file a NOI. Under the BA, debtors could not file a NOI but they could file what is called a 'holding' proposal. ${ }^{21}$ Almost $25 \%$ of the proposals filed under the BA were holding proposals. As expected, holding proposals have almost disappeared under the BIA as they have effectively been made obsolete by the NOI. Over a third of the proposals in both samples have been amended before the creditors' vote.

Under the BIA, debtors spend an average of 40 days under the NOI. Given that it takes, on average, 38 days from the filing of a proposal to the creditor's vote, the average time between filing the NOI and the vote by creditors is 78 days (the median is 52 days). Under the BA, an average of 48 days elapses between filing of a proposal and the creditors' meeting. However, this is skewed by one proposal that took over 4.5 years; the median time between filing and voting under the BA is 24 days. Figure 5 displays the cumulative relative frequency of the time between filing and voting for the two samples. ${ }^{22}$ The proportion of meetings within one month of filing has fallen from over $60 \%$ under the BA to $27 \%$ under the BIA. Under the BA, $85 \%$ of meetings are held within 2 months of filing compared with $56 \%$ for the BIA. The two distributions converge at 7 months, at which point $97 \%$ of the proposals have been voted on under both samples. Not surprisingly, a Wilcoxon rank-sum test easily rejects the hypothesis that the time between filing and voting is the same for the BA and BIA samples.

The introduction of the BIA also impacted on the time firms stay in reorganization. The average time in reorganization has increased from 1,138

\footnotetext{
${ }^{21} \mathrm{~A}$ holding proposal is an interim document filed by firms to give them more time to prepare a full proposal. Holding proposals are risky for firms because they give creditors an option to reject reorganization even before the firm has presented them with the full restructuring plan.

${ }^{22}$ In the BIA sample, the time from filing to voting is measured by the difference between the date a firm files a NOI and the date of the creditors' meeting. In the BA sample, it is measured by the difference between filing and meeting dates.
} 
to 1,323 days. Figure 6 shows the cumulative relative frequency of the time between voting and completion (or failure) for the two samples. Almost onefifth of the firms in the BA sample exit reorganization within the first year compared with less than $5 \%$ of the BIA sample. Firms in the BIA never make up the lost time; even after 8 years, the proportion of firms that have exited under the BIA has not caught up to the BA.

An important feature of a bankruptcy law is its ability to minimize filtering failure, i.e., to identify non-viable firms that attempt reorganization. As previously mentioned, around $75 \%$ of confirmed plans in both samples are completed. Data from both samples show that of the 149 firms that failed to complete plans, $3 \%$ failed within 1 month, $11 \%$ within 3 months, $24 \%$ within 6 months and 56\% within 1 year. ${ }^{23}$ In comparison, Morrison (2007) reports that only between $11 \%$ and $22 \%$ of Chapter 11 firms failed within one year of confirmation.

Table 2 also reports that average (direct) bankruptcy costs are significantly lower for the BIA sample. A reorganization procedure costs $\$ 36,000$ under the BIA compared with $\$ 60,000$ under the BA. However, expressed in proportion to the value of assets, bankruptcy costs have increased significantly from $15 \%$ under the BA to $23 \%$ under the BIA. Trustee's fees represent almost $70 \%$ of bankruptcy costs. The proportion of proposals filed by corporations has fallen from $86 \%$ under the BA to $70 \%$ under the BIA.

In their study of Chapter 11, Baird \& Morrison (2007) report that tax claims are proportionately higher for small businesses. They claim that many small business owners seek Chapter 11 protection merely to deflect personal liability for unpaid taxes. Table 3 reports the ratio of government claims to total claims by asset size for the BA, BIA and both samples. The data confirm that tax liabilities decrease monotonically with firm size. Government claims represent almost $30 \%$ of total claims for firms with less that $\$ 50,000$ in assets but only $4 \%$ for firms with assets over $\$ 1$ million. In addition, government claims at unincorporated businesses are almost twice as high as at incorporated businesses. This phenomenon is clearly associated with the new

\footnotetext{
${ }^{23}$ There is very little difference between the BA and BIA samples.
} 
bankruptcy law. Table 3 reports that the proportion of government claims is relatively constant across firm size in the BA sample whereas it decreases significantly with firm size under the BIA.

To summarize, the data show that the BIA is attracting smaller and weaker firms. Firms restructuring under the BIA negotiate with fewer creditors and those creditors are offered a lower repayment of their claims over a longer period compared with firms reorganizing under the BA. Relative to the BA, firms under the BIA also have higher government claims and a greater number of them are unincorporated businesses. Firms take more time before submitting proposals to a creditors' vote and more time under court supervision. Under the BIA, the reorganization procedure seems to be less costly in nominal terms but the costs capture a larger proportion of the debtors' assets.

\section{Empirical strategy}

To establish the effects of the changes to bankruptcy law we exploit the natural experiment implicitly created by the introduction of the BIA. The control group is represented by firms attempting reorganization under the BA; the treatment group is represented by the firms attempting reorganization under the BIA. We focus our analysis on the two ex post efficiency criteria: that assets are allocated to their highest value use and that the process is not too costly. To assess the impact of the efficient allocation of resources, we examine the different stages of the reorganization process. First, we examine the debtors' decision whether to file a holding proposal or a notice of intention. There are two reasons for filing a holding proposal or a NOI. Either the debtor needs more time to prepare a credible plan or the debtor is trying to buy time. A close examination of the firms using these procedures and the determinants of their choices should be revealing. Second, we estimate probit regressions for the probability that creditors vote in favor of a plan. ${ }^{24}$

\footnotetext{
${ }^{24}$ We do not have data on firms that file a holding proposal or NOI that do not subsequently file a plan.
} 
Assuming that a failed reorganization plan returns less to creditors than immediate liquidation, a failed plan represents a non-value-maximizing outcome. To assess whether asset values are maximized, we also estimate probit regressions for the probability that a plan is completed. The direct costs of reorganization-i.e., fees charged by professionals, such as trustees, lawyers, and accountants, as well as court fees, costs of communication with creditors, filing fees charged by the Superintendent of Bankruptcy, and so on - are observed directly in the data. Indirect bankruptcy costs represent the second component of bankruptcy costs. Following Franks \& Torous (1989) and Thorburn (2000), we proxy indirect costs by the duration of reorganization, defined as the time between filing and completion (or failure). We estimate the impact of the BIA on indirect bankruptcy costs using a proportional hazard function for the duration of reorganization.

We are able to capture separately the effect of each of the changes to bankruptcy law discussed in section 3 . To capture the change in the veto power of large creditors, we construct a dummy variable that takes the value of 1 for firms with a single unsecured creditor owed more than $25 \%$ of unsecured claims, and 0 otherwise. Given the parallel between the filing of a holding proposal under the BA and a notice of intention under the BIA, we examine their impact with a dummy variable taking the value of 1 for firms which filed either a holding proposal or a NOI. The influence of the changing status of secured claims is captured by the ratio of secured claims to total claims. The ratio of government claims to total claims is used to capture the impact of the changing status of Crown claims. Similarly, the ratio of wage claims to total claims is used to capture the impact of the changing status of employee claims.

Additional regression explanatory variables are used to control for the structure of the reorganization proposal, the financial characteristics of firms, and other forms of heterogeneity across firms. Fisher \& Martel (1994) find that creditors are more likely to accept proposals with front-loaded payments, which is consistent with firms attempting to signal financial viability to creditors. This signaling effect is measured by the ratio of payments made within 3 months of approval to total payments in the proposal and a dummy 
variable equal to 1 if the proposal offers a positive cash payment (upon court approval), 0 otherwise. ${ }^{25}$ We investigate several other key variables: the return offered to unsecured creditors (per dollar of claims); a dummy variable equal to 1 if the proposal offers a zero payment; the time between filing and the creditors' meeting, as a measure of the uncertainty faced by creditors; a dummy variable equal to 1 if the proposal was amended before the creditors' vote, indicating successful negotiations prior to the vote; the proportion of ordinary unsecured claims in total claims and the total number of creditors, to capture the complexity of negotiations.

To control for heterogeneity across firms, we use a measure of firm size (the log of real assets or real claims at the time of filing), a dummy variable for firms with zero assets and the ratio of assets to liabilities as an indicator of the firm's financial health. While bankruptcy law falls under federal jurisdiction, there is anecdotal evidence that the de facto enforcement of the law is different between Montreal and Toronto. ${ }^{26}$ Thus, we include a dummy variable for the region where the proposal is filed (Montreal $=1$, Toronto $=0$ ). In addition, given that corporations may present more complex plans to creditors than sole-proprietorships and partnerships and that being owner-managed, sole-proprietorships and partnerships may present fewer moral hazard problems to creditors, we include a dummy variable for the legal structure of the firm (corporation $=1$, sole-proprietorship or partnership $=0$ ). We use the change in the unemployment rate over the 6 months prior to filing to control for the effect of the business cycle. Lastly, we include year and industry (two-digits) dummies.

\footnotetext{
${ }^{25}$ The ratio of payments at 1,6 and 9 months are also investigated.

${ }^{26}$ There are a variety of reasons why this may be so, having to do with differences in the structure of the two economies and even differences in 'bankruptcy culture' (Globe and Mail. 1999. "Quebec is Bankruptcy Hub." May 3). Evidence of 'forum shopping' [LoPucki \& Withford (1991)] suggests Chapter 11 is not immune to differences in enforcement across states.
} 


\section{Estimation Results}

\subsection{Stay of proceedings}

Given that the filing of a holding proposal under the BA or a NOI under the BIA represents the first stage of reorganization, we create a dummy variable taking the value of 1 if a debtor filed either a holding proposal or a NOI, 0 otherwise. Table 4 reports the marginal effects from the probit regressions for the BA (1977-1988) and BIA (1993-2007) samples taken separately and for the full sample $(1977-2007) \cdot{ }^{27}$

The first two columns of Table 4 suggest that there is one common important variable that has a positive and significant impact on the probability of filing either a holding proposal or a NOI: firm size, measured either by assets or claims. Under the BA, the firm's decision also appears to be pro-cyclical. The BIA sample reveals that although the likelihood of filing a holding or a NOI increases with firm size, it is negatively related to the presence of a large ordinary creditor, the proportion of secured, government and ordinary claims. In addition, incorporated businesses are more likely to file than non-incorporated businesses. Column 3 reports the regression results for the full sample including a dummy variable for the BIA period and they confirm the size effect with the coefficients for assets, claims and corporation dummy being highly significant. Corporations are $33 \%$ more likely to file a holding proposal or a NOI. The presence of a large ordinary creditor significantly reduces the likelihood of firms filing a holding proposal or a NOI. The coefficient for the BIA dummy variable is positive and highly significant reflecting the fact that these procedures are more common under the BIA.

Larger firms are likely to require more time to prepare a credible reorganization plan. The firm size effects reported in Table 4 are consistent with this view. Table 4 also shows that the presence of a large ordinary creditor (the

\footnotetext{
${ }^{27}$ The independent variables for these regressions differ from those at other stages of reorganization as many variables (e.g., from the plan itself) are not observed at the first stage and as such cannot influence the firm's decision.
} 
veto variable) and relatively large ordinary and secured claims all reduce the likelihood of holding/NOI proposals. One explanation for these findings is that highly-exposed creditors resist the higher risk that comes with delays to filing a complete plan implicit with a holding proposal or NOI. Resistance by creditors to delays in turn would support the proposition that some debtors use holding proposals or a NOI as a strategic device to buy time.

\subsection{Creditors' vote}

The next stage of the reorganization process is the vote of ordinary creditors.

Table 5 shows the marginal effects on the probability a plan is accepted by ordinary creditors for the BA, the BIA and the full sample. The pseudo- $R^{2}$ values are high given the cross-sectional nature of the data- -0.345 for the BA model and 0.311 for the BIA model. The qualitative effect of four variables (the dummy variable for a holding proposal or a NOI, the ratio of payments within 3 months, the time between filing and voting, and the dummy variable for an amended proposal) are the same across the two samples. Of those that differ, the ratio of government claims, the dummy variable for plans that offer a positive cash payment and dummy variables for Montreal and corporations are significant for the BA but not for the BIA. The ratio of secured, ordinary and wage claims, the proposed payment to ordinary creditors, the dummy variable for a zero payment and the firm size are all significant for the BIA sample but not for the BA. The standard errors are uniformly higher for the BA regression, likely reflecting its smaller sample size.

To examine the impact of the introduction of the BIA, we need to examine the regression results over the full sample. The first five variables in Table 5 account for the impact of the law changes on the creditors' decision. The presence of a single creditor with veto power and the proportion of government claims have no statistically significant impact on the probability of acceptance by creditors. The first result confirms that the presence of a large creditor impacts on the first stage of the reorganization process but not on the vote by creditors. The impact of the ratio of government claims is very interesting. Based on the full sample regression, this variable has no sig- 
nificant effect on the creditors' decision on a reorganization plan. However, columns 1 and 2 report that an increase in the ratio of government claims had a negative and significant impact on the probability of acceptance under the BA but not under the BIA. Yet, data show that the ratio of government claims increased from $5 \%$ under the BA to $19 \%$ under the BIA. ${ }^{28}$ Thus, it appears that the change in the status of government claims under the BIA has eliminated their impact on the outcome of the creditors' meeting.

The dummy variable for filing a holding proposal or a NOI has a negative and highly significant impact on the probability of acceptance of a proposal. This could be because creditors interpret early delays in proceedings as a signal of a weaker firm or simply that creditors punish undue delays. The probability of acceptance also increases with the ratio of secured claims. Recall that under the BA, secured creditors were not covered by a reorganization plan while the BIA potentially gives them a more active role. ${ }^{29}$ Yet their presence has a significant impact on the vote of ordinary unsecured creditors. This is consistent with earlier findings by Fisher \& Martel (1995) who interpret this effect as a signal on the quality of the firm provided by informed secured creditors, who closely monitor their loans and the firm, to less-informed unsecured creditors. Although wage claims represent, on average, $0.4 \%$ of total claims and are present in only one filing out of five, they have a positive impact on the probability of acceptance. Wage creditors are generally favorable to the firm's reorganization. ${ }^{30}$

Regression results also show that the structure of the reorganization contract plays a key role in the creditors' decision. The higher the return offered to ordinary creditors, the more likely they are to accept the proposal. A higher ratio of payments within three months has a highly significant positive impact on the probability a plan is accepted, which is consistent with creditors using cash as a positive signal of a firm's viability [Fisher \& Mar-

\footnotetext{
${ }^{28}$ The largest portion of this increase is due to what are now referred to as 'ordinary' Crown claims; source deduction claims have actually decreased under the BIA.

${ }^{29}$ Secured creditors voted in only 3.5\% (12/346) of the plans between 1997 and 2007.

${ }^{30}$ One should notice that the proportion of files with positive wage claims is significantly lower under the BIA (12.5\%) compared to the BA (32\%).
} 
tel (1995), Martel (2003)]. Reorganization plans offering a zero payment have a significantly lower probability of acceptance. Plans that take longer between filing and voting are less likely to be accepted. This effect is particularly pronounced for the BIA sample. Taken along with the negative effect of the holding proposal/NOI dummy variable, it appears creditors are more sensitive to delays under the BIA. Plans that have been amended are also associated with statistically significant higher acceptance probabilities in both samples, which is evidence of successful negotiations between debtors and creditors.

The probability of acceptance decreases with the size of claims but increases with the proportion of ordinary claims. The first effect indicates that creditors are less favorable to more levered debtors. The second effect confirms that acceptance is more likely when claims are more concentrated perhaps because it facilitates the negotiation process. Interestingly, the results suggest that plans from businesses that have zero assets are more likely to be accepted by creditors. As noted in Table 1, the proportion of files with zero assets has more than tripled since the introduction of the BIA. For firms with zero assets it is possible the reorganization procedure is used to liquidate the debtor's assets in a more structured way to increase the payoff to creditors.

The legal status of the firm has no significant impact on the creditors' decision while proposals filed in Montreal have a lower chance of being accepted, with the effect under the BA being stronger. Acceptance probabilities are not affected by the business cycle prior to filing. Finally, the BIA dummy is positive and weakly significant which suggest that the probability of acceptance has increased since the introduction of the BIA.

\subsection{Plan completion}

The last stage in reorganization is the outcome of the process, i.e., whether the plan is successfully completed by debtors who received creditors' and court confirmation of their plans. Table 6 shows the marginal effects on the 
probability that a plan is successfully completed. None of the variables that measure the impact of the law changes are consistently significant in both samples. In fact, the proportion of payments within 3 months is the only variable which has a positive and highly significant impact on the probability of success in both samples. The regression results also suggest that the change in the status of Crown claims had a positive impact on this stage of reorganization. Under the BA Crown claims had a negative and significant impact on the likelihood of success; this effect has disappeared under the BIA. The results for the full sample support the positive signaling effect of the reorganization contract and secured creditors - the probability of successfully completing a plan increases with the ratio of payments within three months and the proportion of secured claims. Debtors filing a holding proposal or a NOI have a lower chance of succeeding in reorganization. This reinforces the perception that delays in reorganization may reveal a lower quality firm and are used mainly used to buy time. Larger firms measured by the size of claims, with a higher assets to claims ratio and with a higher proportion of ordinary claims are also more likely to complete their reorganization process. Firms filing in Montreal also have a lower probability of completion, the effect being significantly stronger for the BA period. Finally, we cannot reject the hypothesis that the probability of success does not differ between the two samples as the BIA dummy is not significant.

\subsection{Duration of reorganization}

Probit estimation yields only a partial understanding of completion because it ignores data on the duration of the proposal. The raw data (see Figure 6) suggest that reorganization under the BIA takes much longer than under the BA. However, because the samples include proposals that fail as well as those that are completed, reorganization duration regressions cannot be consistently estimated by OLS. Limiting estimation to completed reorganization plans would result in sample selectivity bias. Including failed plans would ignore censoring in the data, since the time to completion is not observed for failed plans. Thus, we estimate duration regressions using the proportional 
hazard function approach. ${ }^{31}$

The hazard rate $h(t, X)$, defines the instantaneous rate of completion conditional upon the firm surviving until time $t$ and a set of covariates $X$. We estimate the log-logistic hazard function:

$$
h(t, X)=\frac{\gamma \lambda(\lambda t)^{\gamma-1}}{1+(\lambda t)^{\gamma}}
$$

where $\lambda=\exp \left\{-\left(\beta_{0}+\beta_{1} x_{1}+\cdots+\beta_{K} x_{K}\right)\right\}$ for the $K$ covariates in the model. A positive $\beta_{i}$ implies that $x_{i}$ has a negative effect on the hazard and, hence, a positive effect on duration. The shape parameter $\gamma$ captures the time evolution of the hazard. This flexibility is useful for there is conflicting evidence on duration dependence from firms reorganizing under Chapter 11. Bandopadhyaya (1994) finds that the hazard function for 74 firms going through Chapter 11 is upward-sloping while Li (1999) finds that the hazard function for Chapter 11 firms is hump-shaped.

Table 7 shows the estimation results for the log-logistic hazard function. The first conclusion is that the duration model for the BA seems to be more robust than for the BIA. Under the BA, duration increases with the presence of a large ordinary creditor but decreases with the proportion of governement, ordinary and secured claims. This last result again supports the signaling role played by secured creditors. Government claims had a significantly negative impact under the BA period but no impact under the BIA, which confirms that the 1992 reforms diminished the role of government claims in the reorganization process. As expected, duration is shorter if the firm has fewer or zero assets but longer if the firm has more claims. The coefficient of the return to ordinary creditors is significant under both regimes but of different sign. Finally, duration is counter-cyclical under the BA and pro-cyclical under the BIA.

The estimates of $\gamma$ from both samples are significantly different from 1 , implying hump-shaped hazard functions, consistent with the Li (1999) finding for Chapter 11. Figure 7 plots the hazard functions for the two samples

\footnotetext{
${ }^{31}$ Proportional hazard models are widely used in duration analysis. Seetharaman and Chintagunta (2003) surveys recent applications.
} 
at the corresponding means. The BA hazard lies everywhere above the BIA hazard which indicates that firms filing under the BA were more likely to complete plans early in the process compared with firms under the BIA.

\section{Discussion}

Official data from the Superintendent of Bankruptcy in Canada show that, in the 15 years following the introduction of the BIA, the ratio of commercial proposals to liquidations increased by a factor of 25 . While the number of commercial liquidations decreased from 14,317 in 1992 to 6,307 in 2007, the number of proposals increased from 280 to 3,241 over the same period. Since the objective of the BIA was to promote the use of reorganization over liquidation, Canadian bankruptcy law reform appears from a narrow perspective to have been an unqualified success. Whether the BIA reform has been welfare-improving overall is another question. One obvious consideration is whether the selection of firms into the reorganization process changed when the BIA was introduced. Had use of the reorganization process remained relatively constant when the BIA came into effect, it could have been argued that the underlying selection process remained unchanged. However, given the drastic increase in use of the reorganization procedure, the assumption that the selection of firms into the process has not changed appears to be untenable.

How might the selection process have changed? There are two main sources for the increasing number of reorganizing firms under the BIA: firms that would have formally liquidated and firms that would have chosen a private workout (i.e., a restructure outside bankruptcy law) had they been subject to the BA.

If the first explanation were valid, one would expect the characteristics of firms in our BIA sample to be similar to firms liquidating under the BA. Using data on over 800 Canadian liquidations under the BA, Martel (1995) and Fisher \& Martel (2009) find that, compared with reorganizing firms, liquidating firms are much smaller, have fewer creditors but a higher proportion 
of secured creditors, have proportionately lower secured claims but higher ordinary and Crown claims, have a much lower asset/claims ratios, and have lower bankruptcy costs but a higher ratio of administrative costs to assets. As reported in Table 1, firms filing for reorganization under the BIA are smaller, have fewer creditors with a higher percentage of secured creditors, report a higher ratio of ordinary claims and Crown claims, a lower assets to claims ratio, lower direct bankruptcy costs and a higher direct bankruptcy costs to assets ratio than those that filed under the BA. Thus, our evidence is consistent with the new law attracting firms that would have liquidated under the old law.

As for the BIA drawing in more firms that would have restructured privately, Gilson \& al. (1990) investigate the factors that influence a firm's choice between a private workout and reorganization under bankruptcy law. They find that firms with fewer creditors and relatively more debt held by banks (and insurance companies) are more likely to choose a private workout. ${ }^{32}$ More recently, Blazy \& al. (2011) have shown that the probability of opting for private negotiation over formal bankruptcy increases with the size of the loan (i.e. proxy for firm size) and the proportion of long term debt and decreases if a firm declares having one bank as its main creditor. Except for the number of creditors, the firms under the BIA do not match these characteristics. A firm will choose to reorganize under bankruptcy law if it is less costly than a private workout. A falling cost of reorganization relative to private workouts under the BIA could also explain increased use of reorganization. ${ }^{33}$ As reported in Table 1, direct bankruptcy costs have fallen significantly following the introduction of the BIA, which is consistent with low-cost firms having been drawn into the process following the law

\footnotetext{
${ }^{32}$ Strictly speaking the Gilson \& al. (1990) finding refers to bank debt, a subset of secured debt. However, since bank debt represents an average of $70 \%$ of secured claims in the BIA sample, arguably there is little difference between the two. In any case, the basic idea that more concentrated borrowings are easier to restructure is equally well represented in terms of secured debt.

${ }^{33}$ It could also be explained by a rise in the cost of private workouts. However, it seems more likely that a change to bankruptcy law would affect the cost of reorganization rather than the cost of private workouts.
} 
change. ${ }^{34}$

Given that the new law is clearly useful to insolvent firms, three questions remain. First, which of the specific changes to the law are most responsible for the upsurge in the use of the procedure? The probit regressions reveal that the presence of a large unsecured creditor had no impact on acceptance and success probabilities. Filing a holding proposal or a notice of intention (NOI) has a negative and significant impact on the reorganization process. The ratio of secured claims to total claims is positively related to creditors' acceptance and the plan completion while it is negatively related to the duration of reorganization. Lowering Crown priority also removed the negative impact on acceptance and completion rates. Finally, the increase in wage claims protection had an unexpected positive effect on acceptance. The prime candidate for the most economically significant impact of the BIA is the enhanced stay of proceedings. Under earlier law, unsecured claims were only subject to a stay when the proposal was filed and secured claims were not subject to a stay of proceedings. Under the new law, all creditors' proceedings are subject to a stay for at least 30 days, which may be extended by the court. The stay of secured and unsecured claims is not available outside of bankruptcy law (unless creditors agree to it) and clearly makes court-supervised reorganization more attractive than a private workout. Under the BIA, the debtor is given - at no cost - the option to freeze all its debt claims for at least 30 days without having to consult creditors for permission. It is perhaps not surprising that so many firms choose to take advantage of the option. Reinforcing the change to the stay proceedings is the removal of priority over most Crown claims, which can now be paid back more slowly.

The second question is how can it be that a new system attracting a larger number of smaller and weaker firms, firms that spend more time in reorganization and offer a lower payment to creditors, has similar acceptance and completion rates? Ceteris paribus, one would expect creditors to adjust their acceptance decisions to take into account the weaker financial health of

\footnotetext{
${ }^{34}$ An alternative explanation is that, in processing more files, trustees have taken advantage of economies of scale, or perhaps the rapidly expanding market has facilitated entry of new trustees and the increased competition has driven fees down.
} 
firms and lower payments spread out over longer periods and that adjustment to be reflected in lower acceptance rates. Similarly, weaker firms would be expected to have lower completion rates. Yet the empirical analysis suggests that, in aggregate, firms under the new regime have similar acceptance and completion rates as those under the old regime. We suggest a couple of explanations for this. First, the BIA has reduced the cost of reorganization, which to some extent offsets the presence of smaller and weaker firms. Second, there is the potential impact of secured creditors at all stages of the reorganization process. Secured creditors have a screening role at the very beginning of the process since they reduce the likelihood that debtors file a holding proposal or a notice of intention, as reported in Table 4. Secured creditors also have a screening role once the debtor files a plan since they have a positive effect on the probability of acceptance and success (Tables 5 and 6). Finally, firms with higher secured claims successfully exit the reorganization process more quickly. Thus, secured creditors could play a key role in the reorganization process by sending a signal to uninformed creditors about a firm's quality.

Finally, there remains the fundamental question raised by Baird \& Rasmussen (2002): are there any economic benefits from saving these firms? If the economic benefits of saving these small, 'mom-and-pop' firms falls short of the economic costs, then the argument for retaining existing reorganization procedures are weakened. The BIA data show not only that firms are significantly smaller with more of them being unincorporated but that many of them have zero assets and large government claims. Creditors under the new law also accept lower payments in more installments over a longer time period and the ratio of bankruptcy costs to assets has significantly increased. All these factors tend to support the Baird \& Rasmussen (2002) view. Yet clearly the new law is allowing many more firms to restructure their capital. The alternative to reorganization for most of these firms would be liquidation. Although typically lower, liquidation costs are non-negligible, leaving very little or nothing for unsecured creditors. In addition, one can argue that if a debtor is able to convince rational creditors to accept a plan, honor the terms of the plan negotiated with the creditors, and successfully exit the 
procedure, it must be because there is something there worth saving. ${ }^{35}$

\section{Conclusion}

In this article, we compare commercial reorganizations before and after changes to Canadian bankruptcy law in 1992 to evaluate the performance of the bankruptcy system. We find that the likelihood that creditors accept a plan and that a plan is successfully completed is largely unaffected by the changes. However, the new law has undoubtedly change the balance of power towards debtors since they now use the notice of intention procedure to buy time and creditors are being offered a lower return over a longer period. There is also strong evidence that firms in reorganization under the new regime have different characteristics and that the huge growth in use of the procedure under the BIA is the result of an increasing propensity of firms to choose formal reorganization over straight bankruptcy.

As mentioned in Section 2, Canadian bankruptcy law takes its origins in the British insolvency law which is considered to be creditor friendly. Over the last century, the law has been modified to make it more debtor friendly, the last major episode being the 1992 amendments. It is believed that the Canadian law is now more debtor oriented and has gotten closer to U.S. Chapter 11 than ever. Yet, we show that there are still significant differences in the outcome generated by both systems. Although, they both attract mostly small businesses, the Canadian system exhibit a significantly higher confirmation and plan completion rate than Chapter 11 and the time in filing to voting (or confirmation) is also significantly lower. However, it is clear that the gap between Canadian law and Chapter 11 has been reduced by the introduction of the BIA.

An interesting finding is that a relatively small change to the legislation has a huge economic effect. While the BIA is undoubtedly more debtor-

\footnotetext{
${ }^{35} \mathrm{~A}$ complete evaluation would require to follow these firms after exiting the reorganization process in order to see how they fare relative to firms that have not been through reorganization. This information is not available at this time.
} 
friendly than the law it replaced, the changes are relatively modest. It is not as if the new law fundamentally changed the spirit of Canadian bankruptcy law by, for example, introducing a reorganization procedure where there was none before. The BA was already relatively debtor-friendly, although less than the U.S. Chapter 11; the BIA merely made it more so by adopting some of the key features of Chapter 11, such as broadening the application of the stay of proceedings and removing government claims from priority status. Nonetheless, the response of firms to the changes has been nothing short of astounding. A related insight is that the selection of firms into the reorganization process - as opposed to other forms of insolvency resolutionis clearly a key to understanding the operation of the bankruptcy system. To the extent that Chapter 11 performs poorly, as many have suggested, attention for large-scale empirical work should be focused on the types of firms that are attracted to Chapter 11 over bankruptcy liquidation and private workouts. Countries that have recently adopted Chapter 11-style procedures will be rich sources of data for these kinds of studies, which should go a long way to helping us understand whether there is such a things as an optimal bankruptcy procedure and, if so, what form it would take. 


\section{References}

Altman E. 1993a. Corporate Financial Distress and Bankruptcy. New York: Wiley.

1993b. "Evaluating the Chapter 11 Bankruptcy-Reorganization Process," 1 Columbia Law Review 1-25.

Baird, D.G. 1986. "The Uneasy Case for Corporate Reorganizations," 15 Journal of Legal Studies 127-147.

. 1993. "Revisiting Auctions in Chapter 11," 36 Journal of Law and Economics 633-653.

Baird, D.G. and R.K. Rasmussen, 2002. "The End of Bankruptcy,", Working Paper No. 173, University of Chicago Law School, 1-46. . 2003. "Chapter 11 at Twilight," 56 Stanford Law Review 673-699.

Baird, D.G., A. Bris and N. Zhu. 2007. "The Dynamics of Large and Small Chapter 11 Cases: An Empirical Study,", Working Paper, University of California, Davis, 1-43.

Baldwin, J., T. Gray, J. Johnson, J. Proctor, M. Rafiquzzaman, and D. Sabourin. 1997. Failing Concerns: Business Bankruptcy in Canada. Ottawa: Statistics Canada Catalogue 61-525-XPE.

Bandopadhyaya, A. 1994. "An Estimation of the Hazard Rate of Firms Under Chapter 11 Protection," 76 Review of Economics and Statistics 346-350.

Bebchuk, L. A. 1988. "A New Approach to Corporate Reorganizations," 101 Harvard Law Review 775-804

Berkovitch, E., and R. Israel. 1998. "The Bankruptcy Decision and Debt Contract Renegotiations," 2 European Finance Review 1-27.

Berkovitch, E., and R. Israel. 1999. "Optimal Bankruptcy Laws across Different Economic Systems," 12 Review of Financial Studies 347-377.

Betker, B.L. 1995. "Management's Incentives, Equity Bargaining Power, 
and Deviations from Absolute Priority in Chapter 11 Bankruptcies," 68 Journal of Business 161-183.

Bharath, S.T., V. Panchapegesan and I. Werner. 2007. "The Changing Nature of Chapter 11," Working paper, Ohio State University, 1-46.

Blazy, R., J. Martel and N. Nigam. 2011. "The Choice Between Informal and Formal restructuring: The Case of French Banks Facing Distressed SMEs", unpublished manuscript, ESSEC Business School, 1-33.

Bradley, M., and M. Rosenzweig. 1992. "The Untenable Case for Chapter 11," 101 Yale Law Journal 1043-1095.

Bris, A., I. Welch, and N. Zhu. 2006. "The Costs of Bankruptcy: Chapter 7 Liquidation versus Chapter 11 Reorganization," 61 Journal of Finance 1253-1303.

Daigle, K.H., and M.T. Maloney. 1994. "Residual Claims in Bankruptcy: An Agency Theory Explanation," 37 Journal of Law and Economics 157-192.

Davydenko, S.A., and J.R. Franks. 2008. "Do Bankruptcy Codes Matter? A Study of Defaults in France, Germany, and the U.K.," 63 Journal of Finance 565-608.

Denis, D.K., and K.J. Rodgers. 2007. "Chapter 11: Duration, Outcome, and Post-Reorganization Performance," 42 Journal of Financial and Quantitative Analysis 101-118.

Eberhart, A.C., W.T. Moore, and R.L. Roenfeldt. 1990. "Security Pricing and Deviations from the Absolute Priority Rule in Bankruptcy Proceedings," 45 Journal of Finance 1457-1469.

Eisenberg, T., and S. Tagashira. 1994. "Should We Abolish Chapter 11? The Evidence from Japan," 23 Journal of Legal Studies 111-157.

Fisher, T.C.G., and J. Martel. 1994. "Will the Bankruptcy Reforms Work: An Empirical of Financial Reorganization in Canada," 20 Canadian Public Policy 265-277. 
1995. "The Creditors' Financial Reorganization Decision: New Evidence from Canadian Data," 11 Journal of Law, Economics and Organization 113-126.

1999. "Should We Abolish Chapter 11? Evidence from Canada," 28 Journal of Legal Studies 233-257.

2003. "The Effect of Bankruptcy Reform on the Number of Corporate Reorganization Proposals," 29 Canadian Public Policy 339-349.

2005. "The Irrelevance of Direct Bankruptcy Costs to the Firms Financial Reorganization Decision," 2 Journal of Empirical Legal Studies $151-170$.

2009. "An Empirical Analysis of the Firm's Reorganization Decision," 30 Finance 121-149.

Flynn, E.M. 1989. "Statistical Analysis of Chapter 11," Washington, D.C.: Administrative Office of the United States Courts.

Franks, J.R., and W.N. Torous. 1989. "An Empirical Investigation of U.S. Firms in Reorganization," 44 Journal of Finance 747-769.

1994. "A Comparison of Financial Recontracting in Distressed Exchanges and Chapter 11 Reorganizations," 35 Journal of Financial Economics 349-370.

Gertner, R., and D. Scharfstein. 1991. "A Theory of Workouts and the Effects of Reorganization Law," 46 Journal of Finance 1189-1222.

Gilson, S.C., K. John, and L.H.P. Lang. 1990. "Troubled Debt Restructurings: An Empirical Study of Private Reorganization of Firms in Default," 27 Journal of Financial Economics 315-353.

Grossman, S.J., and O.D. Hart. 1986. "The Costs and Benefits of Ownership: A Theory of Vertical and Lateral Integration," 94 Journal of Political Economy 691-719.

Hart, O.D. 1995. Firms, Contracts, and Financial Structure. Oxford: Oxford 
University Press. 2000. "Different Approaches to Bankruptcy," National Bureau of Economic Research Working Paper 7921.

Hotchkiss, E.S. 1995. "Postbankruptcy Performance and Management Turnover," 50 Journal of Finance 3-21.

Hotchkiss, E.S. and R. Mooradian. 2004. "Post-Bankruptcy Performance of Public Companies," Working Paper, Boston College and Northeastern University.

Hotchkiss, E.S., K. John, R. Mooradian and K. Thornburn. 2008. "Bankruptcy and the Resolution of Financial Distress," in Handbook of Corporate Finance: Empirical Corporate Finance, Vol. 2, Ch. 14, ed. B. Espen Eckbo, Elsevier/North Holland.

Jensen-Conklin, S. 1992. "Do Confirmed Chapter 11 Plans Consummate? The Results of a Study and Analysis of the Law," 97 Commercial Law Journal 297-331.

Kahl, M. 2002. "Economic Distress, Financial Distress, and Dynamic Liquidation," 57 Journal of Finance 135-168.

La Porta, R., F. Lopez-de-Silanes and A. Shleifer. 1998 "Law and Finance," 106 Journal of Political Economy 1113-1155.

Lawless, R.M. and S.P. Ferris. 2000. "The Direct Costs of Chapter 11 Bankruptcies," 61 University of Pittsburgh Law Review 629-669.

Lawless, R. M. 2007. "Small Business and the 2005 Bankruptcy Law: Should Mom and Apple Pie be Worried?", 31 Southern Illinois University Law Journal 585-619.

Li, K. 1999. "Bayesian Analysis of Duration Models: An Application to Chapter 11 Bankruptcy," 63 Economics Letters 305-312.

LoPucki, L.M. 1983. "The Debtor in Full Control-Systems Failure Under Chapter 11 of the Bankruptcy Code?" 57 American Bankruptcy Law 
Journal 99-126.

2003 "The Nature of the Bankrupt Firm: A Reply to Baird and Rasmussen's The End of Bankruptcy," 56 Stanford Law Review 645670 .

LoPucki, Lynn M., and Joseph W. Doherty. 2004. "The Determinants of Professional Fees in Large Bankruptcy Reorganization Cases," 1 Journal of Empirical Legal Studies 111-141.

Lopucki, Lynn M., and George G. Triantis. 1994. "A Systems Approach to Comparing U.S. and Canadian Reorganization of Financially Distressed Companies," 35 Harvard International Law Review 267-342.

LoPucki, L.M., and W.C. Whitford. 1990. "Bargaining Over Equity's Share in the Bankruptcy Reorganization of Large, Publicly Held Companies," 139 University of Pennsylvania Law Review 125-196.

1991. "Venue Choice and Forum Shopping in the Bankruptcy Reorganization of Large, Publicly Held Companies," Wisconsin Law Review $11-63$.

Martel, J. 1995. "Commercial Bankruptcy in Canada," 3 Canadian Business Economics 53-64.

2003. "The Information Content of Financial Reorganization Contracts," 24 Finance 145-160.

Mooradian, R. M. 1994. "The Effect of Bankruptcy Protection on Investment: Chapter 11 As a Screening Device," 49 Journal of Finance 1403-1430.

Morrison, E. R. 2007. "Bankruptcy Decisionmaking: An Empirical Study of Continuation Bias in Small Business Bankruptcies," 50 Journal of Law and Economics 381-419.

Seetharaman, P.B., and P.K. Chintagunta. 2003. "The Proportional Hazard Model for Purchase Timing: A Comparison of Alternative Specifications," 21 Journal of Business and Economic Statistics 368-382. 
Skeel, D.A. Jr. 2003. "Creditors' Ball: The "New" New Corporate Governance in Chapter 11," Research Paper No. 03-19, Institute of Law and Economics, University of Pennsylvania, 1-44.

Thorburn, K.S. 2000. "Bankruptcy Auctions: Costs, Debt Recovery and Firm Survival," 58 Journal of Financial Economics 337-368.

Triantis, G.G. 1996. "The Interplay Between Liquidation and Reorganization in Bankruptcy: The Role of Screens, Gatekeepers, and Guillotines," 16 International Review of Law and Economics 101-119.

Warren, E. and J. L. Westbrook. 2000. "Financial Characteristics of Businesses in Bankruptcy," 73 American Bankruptcy Law Journal 499-542.

Weiss, L. A. 1990. "Bankruptcy Resolution: Direct Costs and Violation of Absolute Priority," 27 Journal of Financial Economics 285-314.

Weiss, L.A., and K.H. Wruck. 1998. "Information Problems, Conflicts of Interest, and Asset Stripping: Chapter 11's Failure in the Case of Eastern Airlines," 48 Journal of Financial Economics 55-97.

White, M.J. 1983. "Bankruptcy Costs and the New Bankruptcy Code," 38 Journal of Finance 477-488.

1984. "Bankruptcy Liquidation and Reorganization." in Handbook of Modern Finance edited by Dennis E. Logue, Boston: Warren, Gorham and Lamont.

World Bank. 2004. "Doing Business in 2004: Understanding Regulation." 2005. "Doing Business in 2005: Removing Obstacles to Growth." 2006. "Doing Business in 2006: Creating Jobs." 2007. "Doing Business in 2007: How to Reform." 
Figure 1

Canadian Reorganization Process

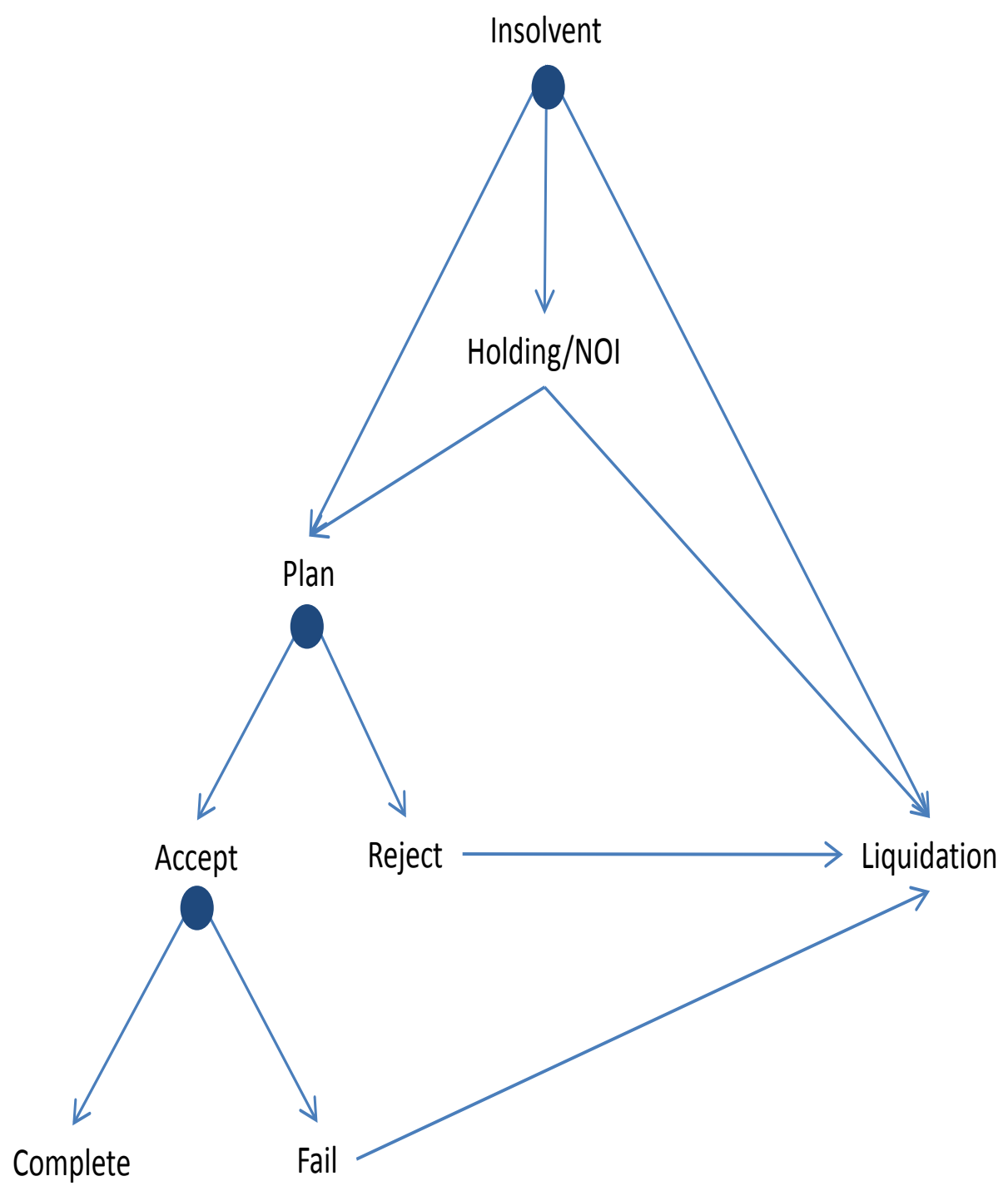




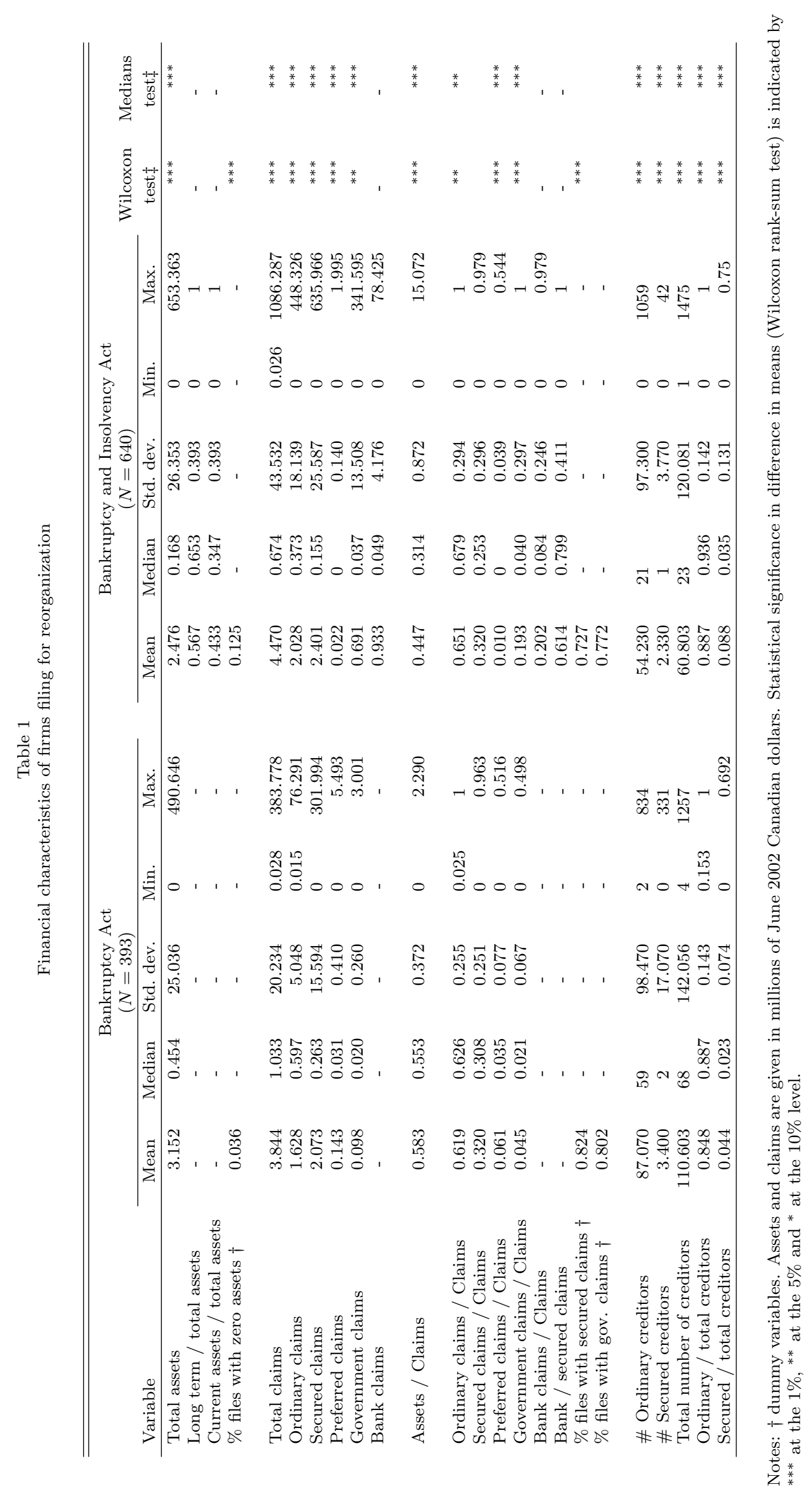


Figure 2

Firm Size by Assets

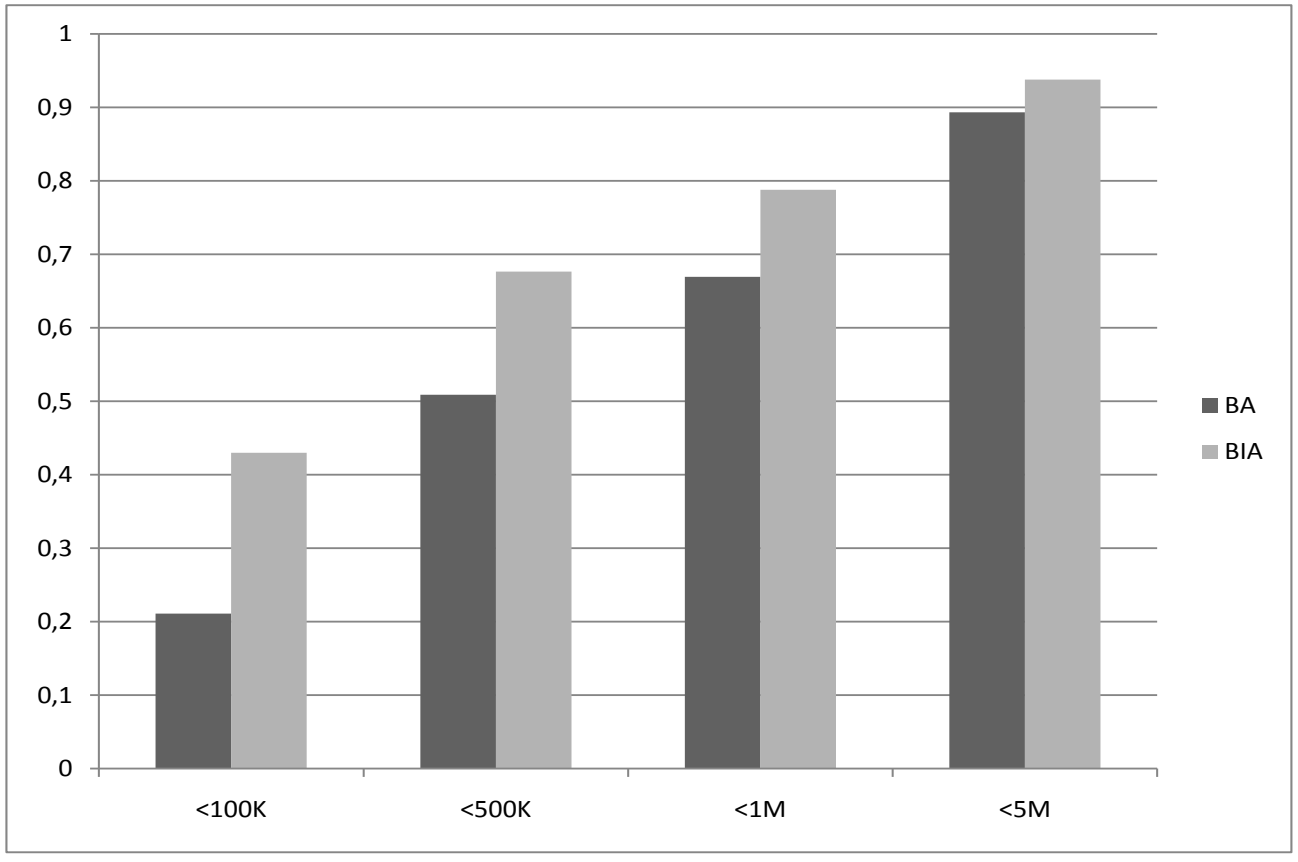


Figure 3

Firm Size by Claims

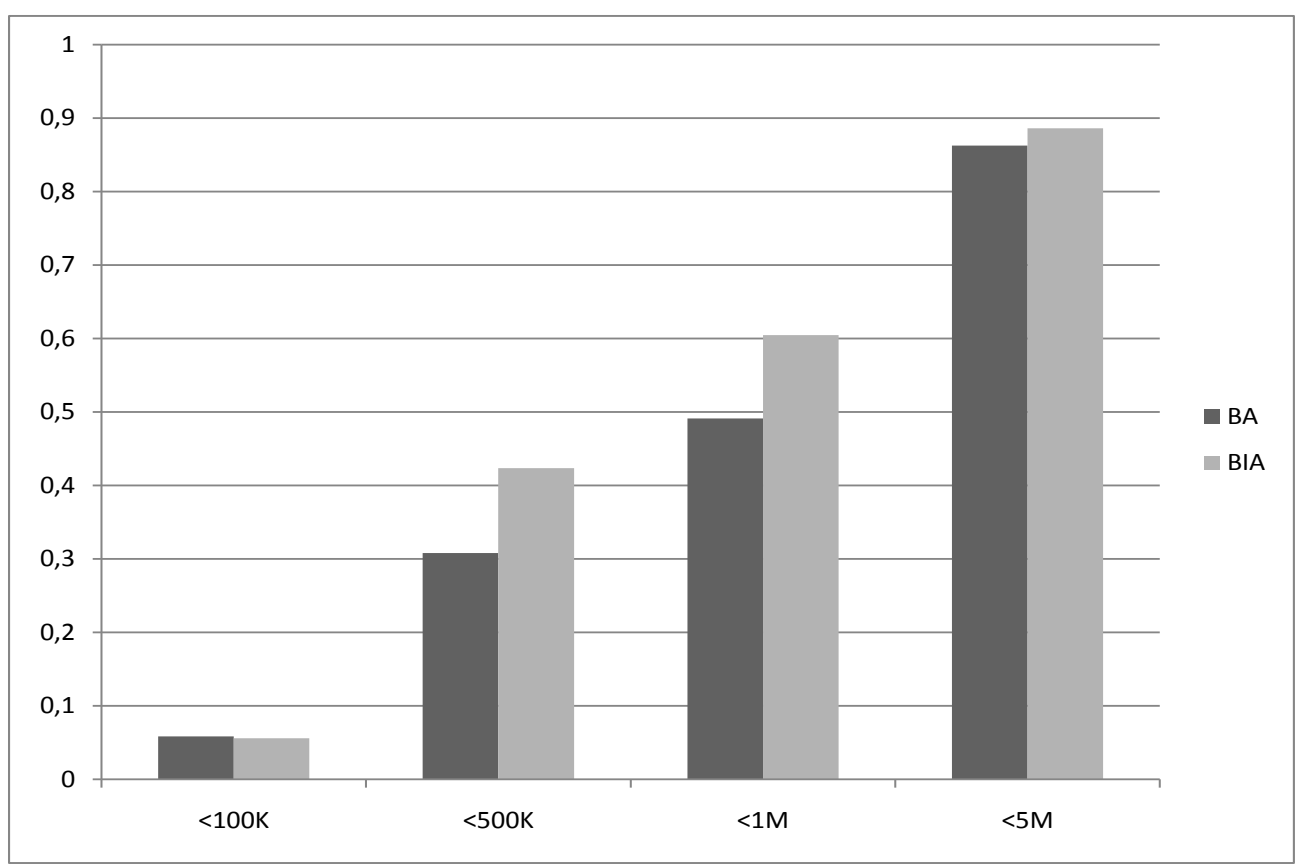




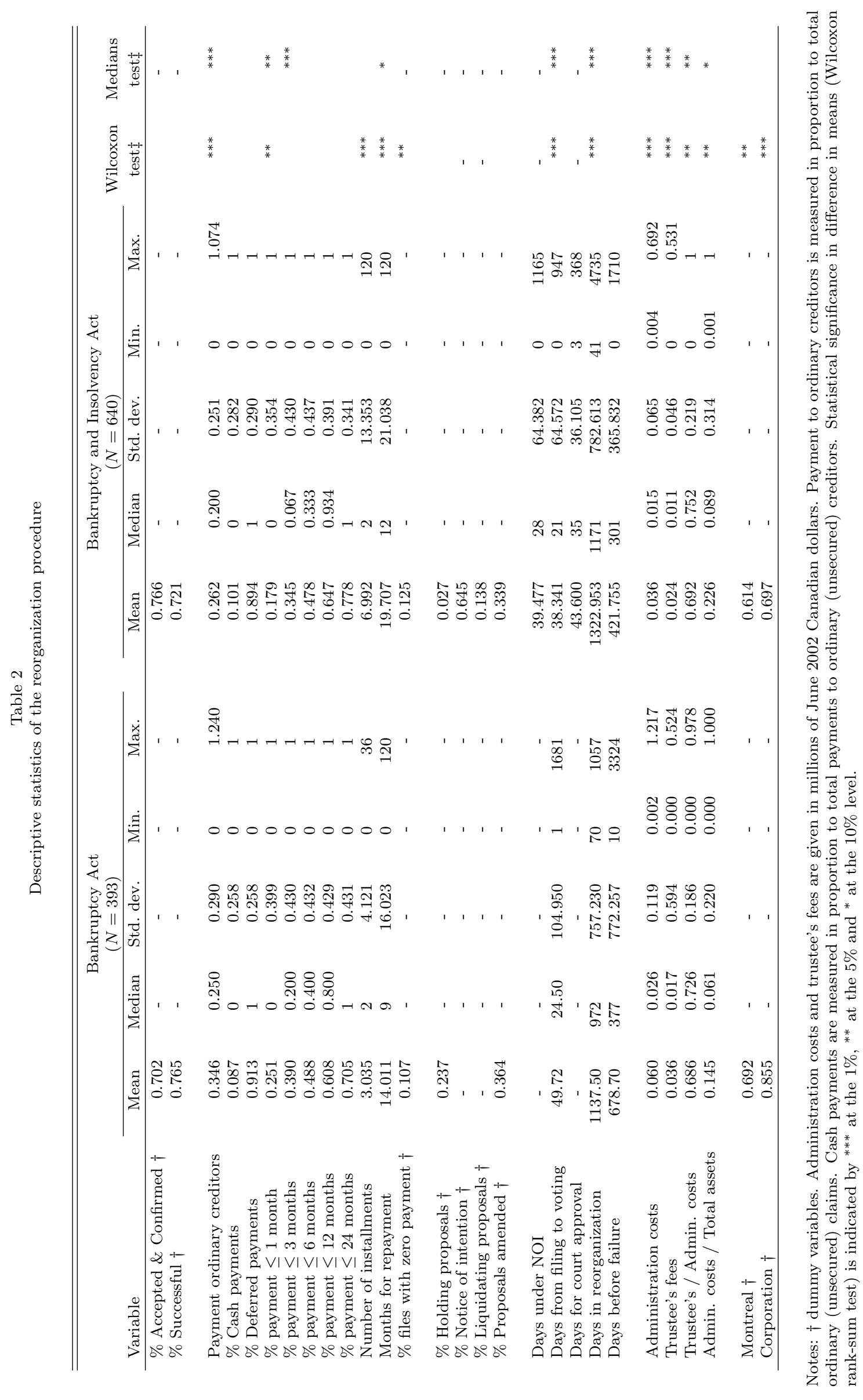


Figure 4

Payment to ordinary creditors.

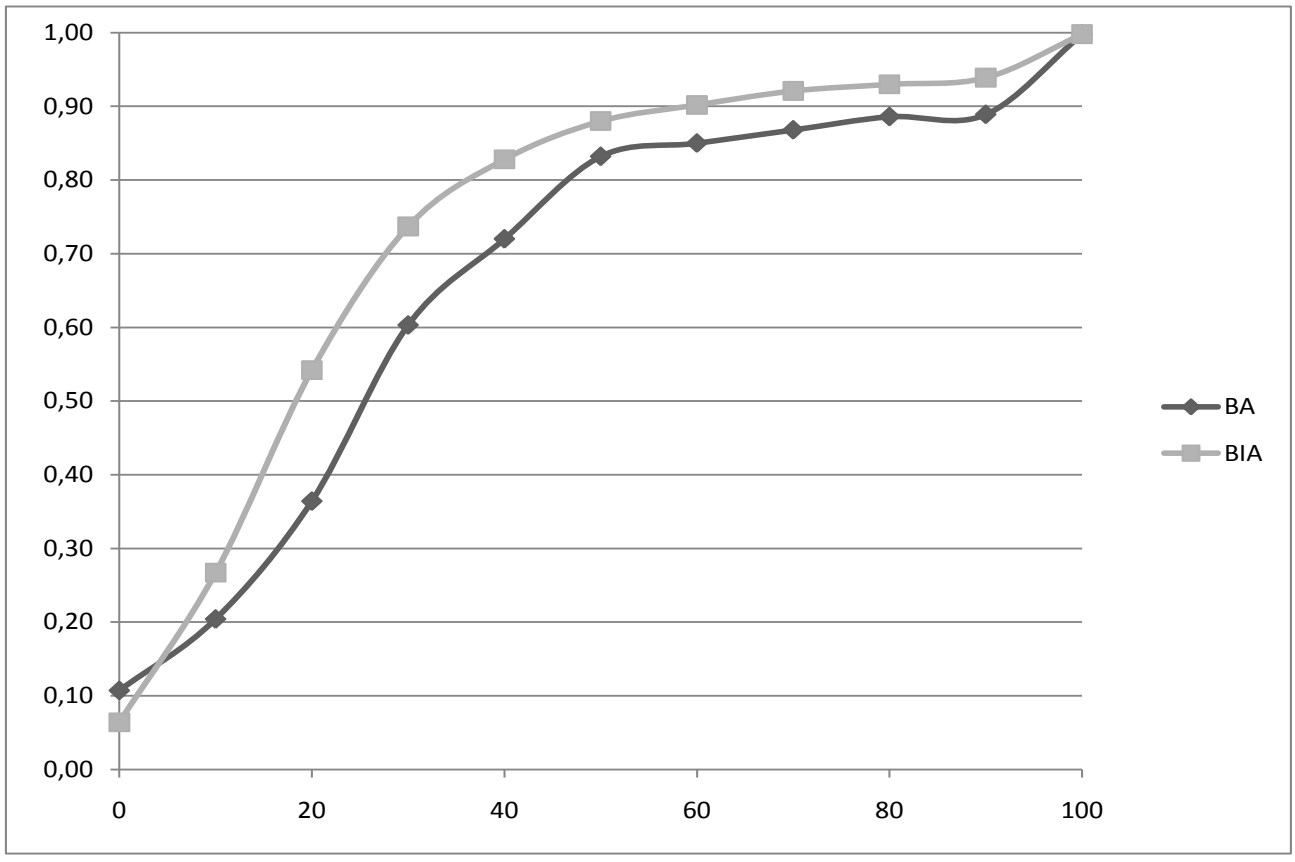


Figure 5

Time (months) between filing and the meeting of creditors.

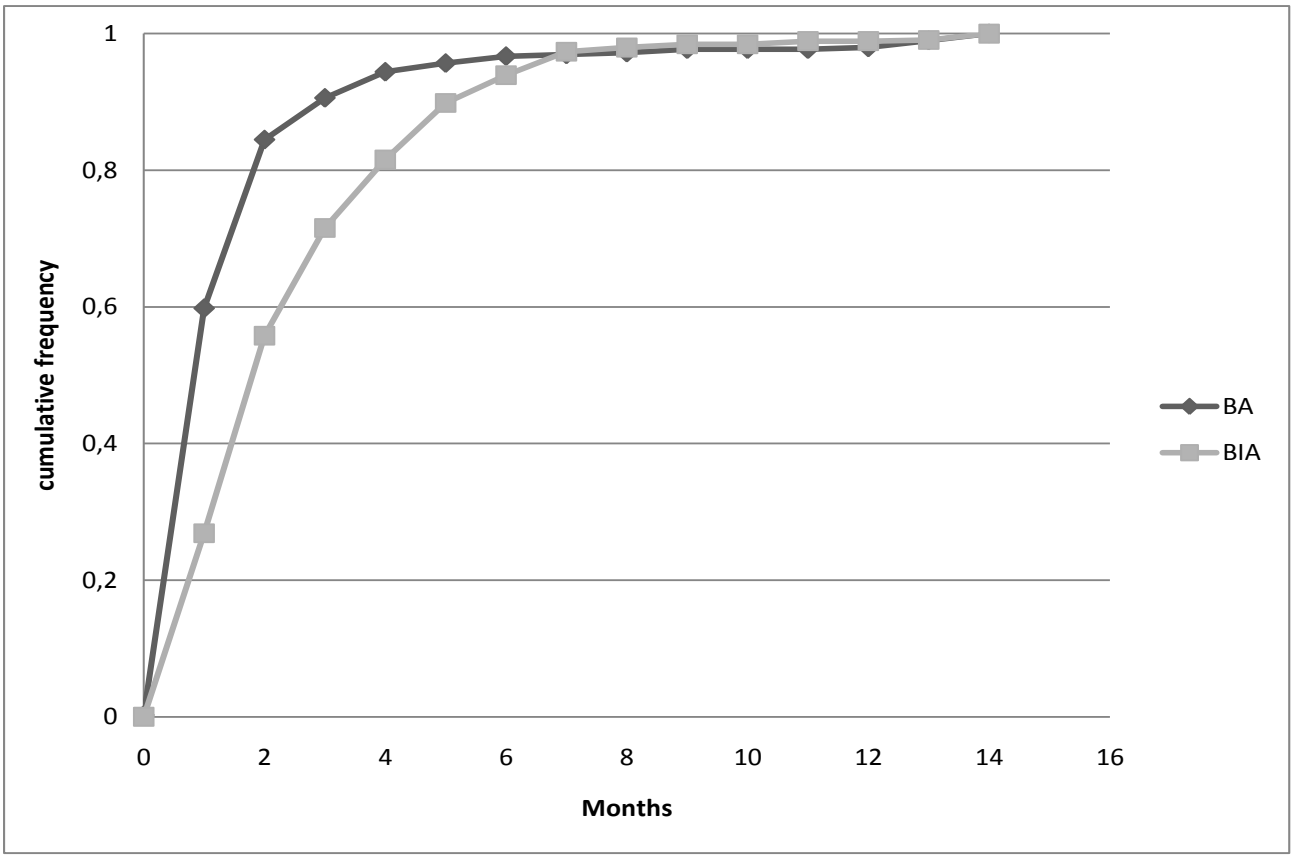


Figure 6

Time (years) between voting and plan completion.

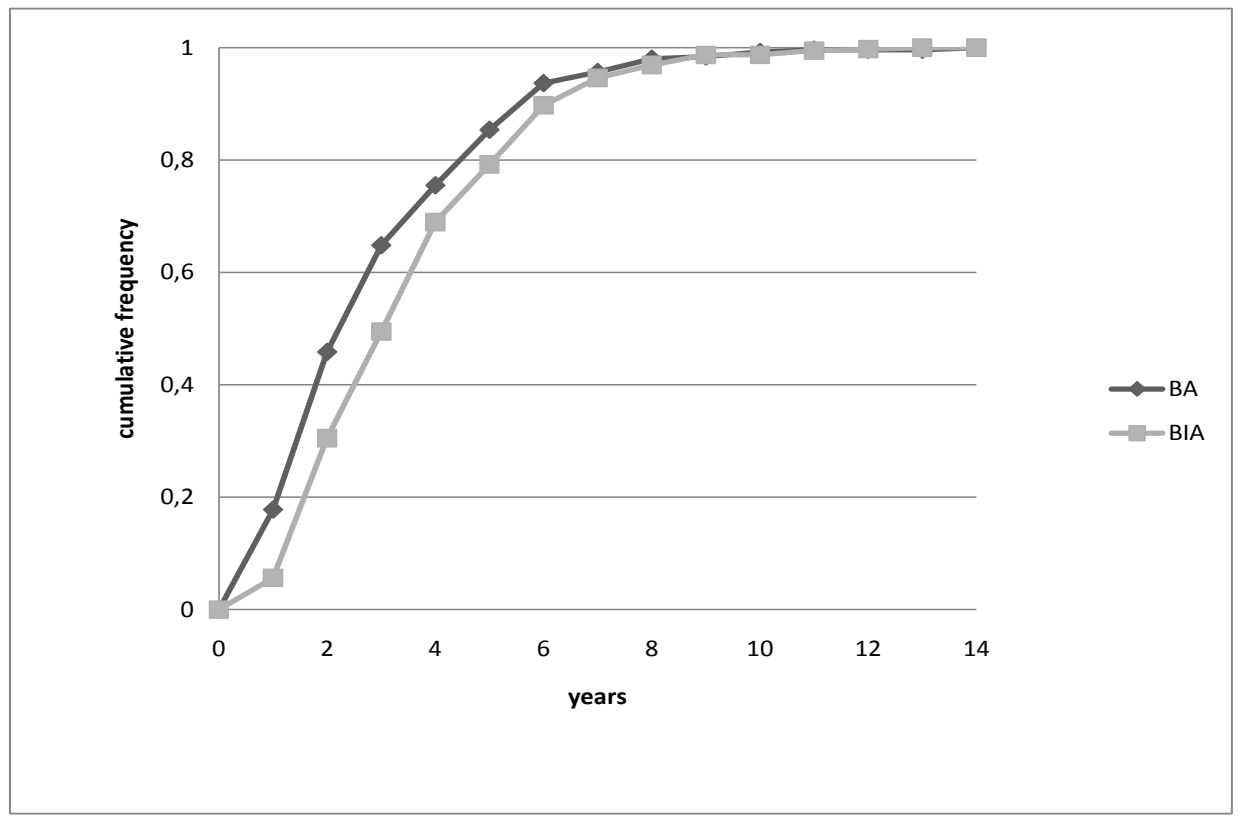


Table 3

Ratio of government claims to total claims by firm size (assets)

\begin{tabular}{cccc}
\hline \hline Firm size (assets) categories & Pooled sample & BA & BIA \\
\hline$[\$ 0, \$ 50 \mathrm{k}]$ & 0.292 & 0.060 & 0.338 \\
]$\$ 50 \mathrm{k}, \$ 100 \mathrm{k}]$ & 0.188 & 0.053 & 0.288 \\
]$\$ 100 \mathrm{k}, \$ 500 \mathrm{k}]$ & 0.091 & 0.036 & 0.132 \\
]$\$ 500 \mathrm{k}, \$ 1,000 \mathrm{k}]$ & 0.079 & 0.053 & 0.103 \\
$>\$ 1,000 \mathrm{k}$ & 0.040 & 0.041 & 0.038 \\
\hline Incorporated & 0.116 & 0.047 & 0.164 \\
Non incorporated & 0.202 & 0.029 & 0.253 \\
\hline
\end{tabular}


Table 4

Probit Regression: Filing a Holding Proposal or Notice of Intention

\begin{tabular}{|c|c|c|c|}
\hline Variable & $\mathrm{BA}$ & BIA & Pooled Sample \\
\hline Veto (dummy) & $\begin{array}{c}-0.044 \\
(0.038)\end{array}$ & $\begin{array}{c}-0.118^{* *} \\
(0.052)\end{array}$ & $\begin{array}{c}-0.117^{* * *} \\
(0.047)\end{array}$ \\
\hline$\%$ Secured claims & $\begin{array}{c}0.161 \\
(0.497)\end{array}$ & $\begin{array}{c}-0.745^{* * *} \\
(0.310)\end{array}$ & $\begin{array}{c}-0.474^{* *} \\
(0.246)\end{array}$ \\
\hline$\%$ Government claims & $\begin{array}{c}-0.003 \\
(0.631)\end{array}$ & $\begin{array}{c}-0.221^{* * *} \\
(0.095)\end{array}$ & $\begin{array}{c}-0.110 \\
(0.096)\end{array}$ \\
\hline$\%$ Wage claims & $\begin{array}{c}-0.110 \\
(1.378)\end{array}$ & $\begin{array}{c}0.494 \\
(0.509)\end{array}$ & $\begin{array}{c}0.796 \\
(1.073)\end{array}$ \\
\hline$\%$ Ordinary claims & $\begin{array}{c}0.176 \\
(0.513)\end{array}$ & $\begin{array}{c}-0.627^{* *} \\
(0.302)\end{array}$ & $\begin{array}{r}-0.395^{*} \\
(0.235)\end{array}$ \\
\hline ln Number creditors & $\begin{array}{c}0.035 \\
(0.031)\end{array}$ & $\begin{array}{r}-0.013 \\
(0.027)\end{array}$ & $\begin{array}{c}0.011 \\
(0.026)\end{array}$ \\
\hline ln Total assets & $\begin{array}{l}0.031^{* * *} \\
(0.010)\end{array}$ & $\begin{array}{l}0.018^{* * *} \\
(0.006)\end{array}$ & $\begin{array}{l}0.020^{* * *} \\
(0.007)\end{array}$ \\
\hline In Total claims & $\begin{array}{r}0.043^{*} \\
(0.023)\end{array}$ & $\begin{array}{c}0.027 \\
(0.021)\end{array}$ & $\begin{array}{l}0.060^{* * *} \\
(0.021)\end{array}$ \\
\hline Assets / Claims & $\begin{array}{c}-0.028 \\
(0.060)\end{array}$ & $\begin{array}{c}-0.007 \\
(0.030)\end{array}$ & $\begin{array}{c}0.028 \\
(0.037)\end{array}$ \\
\hline Montreal (dummy) & $\begin{array}{c}0.057 \\
(0.036)\end{array}$ & $\begin{array}{c}0.075 \\
(0.083)\end{array}$ & $\begin{array}{c}0.078 \\
(0.055)\end{array}$ \\
\hline Corporations (dummy) & $\begin{array}{c}0.082 \\
(0.042)\end{array}$ & $\begin{array}{l}0.360^{* * *} \\
(0.054)\end{array}$ & $\begin{array}{l}0.325^{* * *} \\
(0.044)\end{array}$ \\
\hline$\Delta$ Unemployment & $\begin{array}{c}0.066^{*} \\
(0.036)\end{array}$ & $\begin{array}{r}-0.108 \\
(0.071)\end{array}$ & $\begin{array}{c}0.025 \\
(0.051)\end{array}$ \\
\hline BIA (dummy) & & & $\begin{array}{l}0.470^{* * *} \\
(0.142)\end{array}$ \\
\hline Industry dummies & Yes & Yes & Yes \\
\hline Year dummies & Yes & Yes & Yes \\
\hline$N$ & 393 & 623 & 1033 \\
\hline $\begin{array}{l}\ln L \\
\text { pseudo- } R^{2}\end{array}$ & $\begin{array}{r}-131.030 \\
0.3907\end{array}$ & $\begin{array}{r}-297.128 \\
0.2719\end{array}$ & $\begin{array}{r}-452.596 \\
0.3677\end{array}$ \\
\hline
\end{tabular}

Marginal effects at the mean values from probit regressions. Standard errors are in parentheses with ${ }^{* * *}\left({ }^{* *},{ }^{*}\right)$ denoting statistical significance at the $1 \%(5 \%, 10 \%)$ level (two-tailed test). 
Table 5

Probit Regression: Acceptance by Ordinary Creditors

\begin{tabular}{|c|c|c|c|}
\hline Variable & $\mathrm{BA}$ & BIA & Pooled Sample \\
\hline Veto (dummy) & $\begin{array}{r}-0.046 \\
(0.044)\end{array}$ & $\begin{array}{r}-0.000 \\
(0.034)\end{array}$ & $\begin{array}{r}-0.009 \\
(0.029)\end{array}$ \\
\hline Holding / NOI (dummy) & $\begin{array}{r}-0.160^{*} \\
(0.092)\end{array}$ & $\begin{array}{l}-0.105^{* * *} \\
(0.031)\end{array}$ & $\begin{array}{c}-0.067^{* *} \\
(0.033)\end{array}$ \\
\hline$\%$ Secured claims & $\begin{array}{c}-0.669 \\
(0.610)\end{array}$ & $\begin{array}{l}0.619^{* * *} \\
(0.170)\end{array}$ & $\begin{array}{l}0.641^{* * *} \\
(0.184)\end{array}$ \\
\hline$\%$ Government claims & $\begin{array}{c}-1.452^{* *} \\
(0.686)\end{array}$ & $\begin{array}{c}0.039 \\
(0.066)\end{array}$ & $\begin{array}{c}-0.018 \\
(0.070)\end{array}$ \\
\hline$\%$ Wage claims & $\begin{array}{l}1.631 \\
(1.754)\end{array}$ & $\begin{array}{l}0.473^{* * *} \\
(0.189)\end{array}$ & $\begin{array}{l}0.607^{*} \\
(0.363)\end{array}$ \\
\hline Return to creditors & $\begin{array}{c}0.082 \\
(0.084)\end{array}$ & $\begin{array}{l}0.205^{* * *} \\
(0.067)\end{array}$ & $\begin{array}{l}0.113^{* *} \\
(0.054)\end{array}$ \\
\hline$\%$ Payments $\leq 3$ months & $\begin{array}{l}0.182^{* * *} \\
(0.053)\end{array}$ & $\begin{array}{l}0.094^{* * *} \\
(0.037)\end{array}$ & $\begin{array}{l}0.132^{* * *} \\
(0.033)\end{array}$ \\
\hline Zero return (dummy) & $\begin{array}{r}-0.064 \\
(0.102)\end{array}$ & $\begin{array}{l}-0.247^{* * *} \\
(0.100)\end{array}$ & $\begin{array}{l}-0.182^{* * *} \\
(0.072)\end{array}$ \\
\hline Cash payments (dummy) & $\begin{array}{c}-0.178^{* *} \\
(0.091)\end{array}$ & $\begin{array}{r}-0.062 \\
(0.054)\end{array}$ & $\begin{array}{r}-0.059 \\
(0.046)\end{array}$ \\
\hline ln Time to vote & $\begin{array}{r}-0.062^{*} \\
(0.038)\end{array}$ & $\begin{array}{l}-0.153^{* * *} \\
(0.024)\end{array}$ & $\begin{array}{l}-0.129^{* * *} \\
(0.021)\end{array}$ \\
\hline Amended proposal (dummy) & $\begin{array}{l}0.329^{* * *} \\
(0.041)\end{array}$ & $\begin{array}{l}0.259^{* * *} \\
(0.026)\end{array}$ & $\begin{array}{l}0.285^{* * *} \\
(0.025)\end{array}$ \\
\hline$\%$ Ordinary claims & $\begin{array}{c}-0.858 \\
(0.611)\end{array}$ & $\begin{array}{l}0.536^{* * *} \\
(0.160)\end{array}$ & $\begin{array}{l}0.514^{* * *} \\
(0.173)\end{array}$ \\
\hline ln Number creditors & $\begin{array}{c}0.000 \\
(0.033)\end{array}$ & $\begin{array}{l}0.010 \\
(0.017)\end{array}$ & $\begin{array}{c}0.013 \\
(0.016)\end{array}$ \\
\hline ln Total assets & $\begin{array}{r}-0.048 \\
(0.047)\end{array}$ & $\begin{array}{l}0.028^{* * *} \\
(0.011)\end{array}$ & $\begin{array}{l}0.019^{*} \\
(0.011)\end{array}$ \\
\hline ln Total claims & $\begin{array}{c}0.016 \\
(0.053)\end{array}$ & $\begin{array}{l}-0.043^{* * *} \\
(0.015)\end{array}$ & $\begin{array}{l}-0.049^{* * *} \\
(0.014)\end{array}$ \\
\hline Zero assets (dummy) & $\begin{array}{c}-0.448 \\
(0.998)\end{array}$ & $\begin{array}{l}0.157^{* * *} \\
(0.031)\end{array}$ & $\begin{array}{r}0.149^{*} \\
(0.046)\end{array}$ \\
\hline Assets / Claims & $\begin{array}{r}-0.021 \\
(0.121)\end{array}$ & $\begin{array}{c}0.000 \\
(0.012)\end{array}$ & $\begin{array}{c}0.002 \\
(0.019)\end{array}$ \\
\hline Montreal (dummy) & $\begin{array}{l}-0.116^{* * *} \\
(0.037)\end{array}$ & $\begin{array}{c}0.028 \\
(0.052)\end{array}$ & $\begin{array}{r}-0.056^{*} \\
(0.030)\end{array}$ \\
\hline Corporations (dummy) & $\begin{array}{r}-0.106^{*} \\
(0.043)\end{array}$ & $\begin{array}{c}0.020 \\
(0.043)\end{array}$ & $\begin{array}{c}-0.009 \\
(0.037)\end{array}$ \\
\hline$\Delta$ Unemployment & $\begin{array}{c}0.007 \\
(0.038)\end{array}$ & $\begin{array}{c}0.012 \\
(0.046)\end{array}$ & $\begin{array}{c}0.024 \\
(0.032)\end{array}$ \\
\hline BIA (dummy) & & & $\begin{array}{c}0.236^{*} \\
(0.133)\end{array}$ \\
\hline Industry dummies & Yes & Yes & Yes \\
\hline Year dummies & Yes & Yes & Yes \\
\hline$N$ & 387 & 638 & 1028 \\
\hline $\begin{array}{l}\ln L \\
\text { pseudo- } R^{2}\end{array}$ & $\begin{array}{r}-144.225 \\
0.3446\end{array}$ & $\begin{array}{r}-229.712 \\
0.3131\end{array}$ & $\begin{array}{r}-418.113 \\
0.2483\end{array}$ \\
\hline
\end{tabular}

Marginal effects at the mean values from probit regressions. Standard errors are in parentheses with ${ }^{* * *}$ $\left(*^{* *},{ }^{*}\right)$ denoting statistical significance at the $1 \%(5 \%, 10 \%)$ level (two-tailed test). 
Table 6

Probit Regression: Successful Plan Completion

\begin{tabular}{|c|c|c|c|}
\hline Variable & $\mathrm{BA}$ & BIA & Pooled Sample \\
\hline Veto (dummy) & $\begin{array}{c}0.082 \\
(0.052)\end{array}$ & $\begin{array}{r}-0.003 \\
(0.051)\end{array}$ & $\begin{array}{c}0.032 \\
(0.037)\end{array}$ \\
\hline Holding / NOI (dummy) & $\begin{array}{r}-0.154 \\
(0.114)\end{array}$ & $\begin{array}{r}-0.092^{*} \\
(0.049)\end{array}$ & $\begin{array}{l}-0.108^{* * *} \\
(0.043)\end{array}$ \\
\hline$\%$ Secured claims & $\begin{array}{r}-1.091 \\
(0.682)\end{array}$ & $\begin{array}{l}0.926^{* * *} \\
(0.361)\end{array}$ & $\begin{array}{l}0.587^{* * *} \\
(0.248)\end{array}$ \\
\hline$\%$ Government claims & $\begin{array}{l}-1.686^{* *} \\
(0.799)\end{array}$ & $\begin{array}{r}-0.030 \\
(0.106)\end{array}$ & $\begin{array}{c}-0.011 \\
(0.093)\end{array}$ \\
\hline$\%$ Wage claims & $\begin{array}{l}1.219 \\
(2.124)\end{array}$ & $\begin{array}{l}0.703 \\
(0.703)\end{array}$ & $\begin{array}{l}1.910 \\
(1.821)\end{array}$ \\
\hline Return to creditors & $\begin{array}{c}0.072 \\
(0.102)\end{array}$ & $\begin{array}{l}-1.980^{* *} \\
(0.094)\end{array}$ & $\begin{array}{r}-0.056 \\
(0.069)\end{array}$ \\
\hline$\%$ Payments $\leq 3$ months & $\begin{array}{l}0.319^{* * *} \\
(0.063)\end{array}$ & $\begin{array}{l}0.260^{* * *} \\
(0.057)\end{array}$ & $\begin{array}{l}0.261^{* * *} \\
(0.041)\end{array}$ \\
\hline Zero return (dummy) & $\begin{array}{c}0.009 \\
(0.120)\end{array}$ & $\begin{array}{c}0.003 \\
(0.125)\end{array}$ & $\begin{array}{c}-0.032 \\
(0.092)\end{array}$ \\
\hline Cash payments (dummy) & $\begin{array}{c}0.019 \\
(0.079)\end{array}$ & $\begin{array}{c}0.093 \\
(0.064)\end{array}$ & $\begin{array}{c}0.054 \\
(0.049)\end{array}$ \\
\hline ln Time to vote & $\begin{array}{c}0.007 \\
(0.036)\end{array}$ & $\begin{array}{c}0.008 \\
(0.042)\end{array}$ & $\begin{array}{c}0.015 \\
(0.027)\end{array}$ \\
\hline Amended proposal (dummy) & $\begin{array}{c}0.042 \\
(0.060)\end{array}$ & $\begin{array}{r}-0.030 \\
(0.048)\end{array}$ & $\begin{array}{c}-0.001 \\
(0.036)\end{array}$ \\
\hline$\%$ Ordinary claims & $\begin{array}{r}-1.018 \\
(0.680)\end{array}$ & $\begin{array}{l}1.029^{* * *} \\
(0.354)\end{array}$ & $\begin{array}{l}0.695^{* * *} \\
(0.240)\end{array}$ \\
\hline ln Number creditors & $\begin{array}{c}0.033 \\
(0.042)\end{array}$ & $\begin{array}{r}-0.043 \\
(0.027)\end{array}$ & $\begin{array}{r}-0.013 \\
(0.022)\end{array}$ \\
\hline ln Total assets & $\begin{array}{r}-0.011 \\
(0.045)\end{array}$ & $\begin{array}{r}-0.027 \\
(0.033)\end{array}$ & $\begin{array}{r}-0.028 \\
(0.024)\end{array}$ \\
\hline ln Total claims & $\begin{array}{c}0.011 \\
(0.050)\end{array}$ & $\begin{array}{l}0.075^{* *} \\
(0.036)\end{array}$ & $\begin{array}{l}0.060^{* *} \\
(0.026)\end{array}$ \\
\hline Zero assets (dummy) & $\begin{array}{c}0.011 \\
(0.507)\end{array}$ & $\begin{array}{c}-0.418 \\
(0.424)\end{array}$ & $\begin{array}{c}0.374 \\
(0.348)\end{array}$ \\
\hline Assets / Claims & $\begin{array}{c}0.095 \\
(0.119)\end{array}$ & $\begin{array}{c}0.112 \\
(0.100)\end{array}$ & $\begin{array}{r}0.124^{*} \\
(0.073)\end{array}$ \\
\hline Montreal (dummy) & $\begin{array}{l}-0.149^{* * *} \\
(0.052)\end{array}$ & $\begin{array}{c}-0.095 \\
(0.083)\end{array}$ & $\begin{array}{r}-0.086^{*} \\
(0.043)\end{array}$ \\
\hline Corporations (dummy) & $\begin{array}{c}-0.061 \\
(0.066)\end{array}$ & $\begin{array}{c}-0.043 \\
(0.063)\end{array}$ & $\begin{array}{r}-0.050 \\
(0.045)\end{array}$ \\
\hline$\Delta$ Unemployment & $\begin{array}{r}-0.102^{*} \\
(0.053)\end{array}$ & $\begin{array}{c}0.084 \\
(0.080)\end{array}$ & $\begin{array}{c}-0.026 \\
(0.043)\end{array}$ \\
\hline BIA (dummy) & & & $\begin{array}{c}-0.088 \\
(0.152)\end{array}$ \\
\hline Industry dummies & Yes & Yes & Yes \\
\hline Year dummies & Yes & Yes & Yes \\
\hline$N$ & 266 & 451 & 729 \\
\hline $\begin{array}{l}\ln L \\
\text { pseudo- } R^{2}\end{array}$ & $\begin{array}{r}-107.359 \\
0.2627\end{array}$ & $\begin{array}{r}-210.607 \\
0.2172\end{array}$ & $\begin{array}{r}-341.770 \\
0.1849\end{array}$ \\
\hline
\end{tabular}

Marginal effects at the mean values from probit regressions. Standard errors are in parentheses with ${ }^{* * *}$ $\left(* *,{ }^{*}\right)$ denoting statistical significance at the $1 \%(5 \%, 10 \%)$ level (two-tailed test). 
Table 7

Duration Analysis: Log-Logistic Estimates

\begin{tabular}{|c|c|c|}
\hline Variable & $\mathrm{BA}$ & BIA \\
\hline Veto (dummy) & $\begin{array}{l}0.343^{* *} \\
(0.158)\end{array}$ & $\begin{array}{c}-0.032 \\
(0.105)\end{array}$ \\
\hline Holding / NOI (dummy) & $\begin{array}{c}0.234 \\
(0.238)\end{array}$ & $\begin{array}{r}-0.166 \\
(0.146)\end{array}$ \\
\hline$\%$ Secured claims & $\begin{array}{l}-5.313^{* *} \\
(2.711)\end{array}$ & $\begin{array}{r}-0.143 \\
(0.732)\end{array}$ \\
\hline$\%$ Government claims & $\begin{array}{l}-7.713^{* * *} \\
(2.863)\end{array}$ & $\begin{array}{c}0.093 \\
(0.227)\end{array}$ \\
\hline$\%$ Wage claims & $\begin{array}{c}8.612 \\
(7.374)\end{array}$ & $\begin{array}{l}1.088 \\
(5.362)\end{array}$ \\
\hline$\%$ Ordinary claims & $\begin{array}{l}-6.033^{* *} \\
(2.784)\end{array}$ & $\begin{array}{c}0.104 \\
(0.699)\end{array}$ \\
\hline Return to creditors & $\begin{array}{l}0.559^{* *} \\
(0.281)\end{array}$ & $\begin{array}{l}-0.524^{* * *} \\
(0.200)\end{array}$ \\
\hline$\%$ Payments $\leq 3$ months & $\begin{array}{c}0.226 \\
(0.195)\end{array}$ & $\begin{array}{l}0.056 \\
(0.132)\end{array}$ \\
\hline Zero return (dummy) & $\begin{array}{r}-0.042 \\
(0.296)\end{array}$ & $\begin{array}{r}-0.093 \\
(0.251)\end{array}$ \\
\hline Cash payments (dummy) & $\begin{array}{c}0.331 \\
(0.231)\end{array}$ & $\begin{array}{r}0.340^{*} \\
(0.202)\end{array}$ \\
\hline ln Time to vote & $\begin{array}{c}0.074 \\
(0.128)\end{array}$ & $\begin{array}{c}-0.071 \\
(0.079)\end{array}$ \\
\hline Amended proposal (dummy) & $\begin{array}{r}-0.196 \\
(0.136)\end{array}$ & $\begin{array}{c}0.118 \\
(0.099)\end{array}$ \\
\hline Zero assets (dummy) & $\begin{array}{l}-3.890^{* * *} \\
(1.294)\end{array}$ & $\begin{array}{c}-0.275 \\
(0.635)\end{array}$ \\
\hline Assets / Claims & $\begin{array}{l}0.148 \\
(0.341)\end{array}$ & $\begin{array}{l}0.088 \\
(0.109)\end{array}$ \\
\hline ln Total assets & $\begin{array}{l}-0.309^{* * *} \\
(0.114)\end{array}$ & $\begin{array}{c}-0.032 \\
(0.057)\end{array}$ \\
\hline ln Total claims & $\begin{array}{r}0.275^{*} \\
(0.144)\end{array}$ & $\begin{array}{r}0.126^{*} \\
(0.066)\end{array}$ \\
\hline ln Number creditors & $\begin{array}{c}0.017 \\
(0.111)\end{array}$ & $\begin{array}{c}-0.069 \\
(0.065)\end{array}$ \\
\hline Montreal (dummy) & $\begin{array}{c}-0.191 \\
(0.160)\end{array}$ & $\begin{array}{r}-0.349^{*} \\
(0.180)\end{array}$ \\
\hline Corporations (dummy) & $\begin{array}{c}-0.216 \\
(0.227)\end{array}$ & $\begin{array}{c}-0.152 \\
(0.138)\end{array}$ \\
\hline$\Delta$ Unemployment & $\begin{array}{l}-0.338^{* * *} \\
(0.123)\end{array}$ & $\begin{array}{l}0.518^{* * *} \\
(0.160)\end{array}$ \\
\hline Industry dummies & Yes & Yes \\
\hline Year dummies & Yes & Yes \\
\hline$\gamma$ & $\begin{array}{l}0.254^{* * *} \\
(0.029)\end{array}$ & $\begin{array}{l}0.286^{* * *} \\
(0.022)\end{array}$ \\
\hline $\begin{array}{l}N \\
\ln L\end{array}$ & $\begin{array}{l}251 \\
-64.084\end{array}$ & $\begin{array}{l}389 \\
-142.492\end{array}$ \\
\hline
\end{tabular}

Standard errors are in parentheses with ${ }^{* * *}\left({ }^{* *},{ }^{*}\right)$ denoting statistical significance at the $1 \%(5 \%, 10 \%)$ level (two-tailed test). 
Figure 7

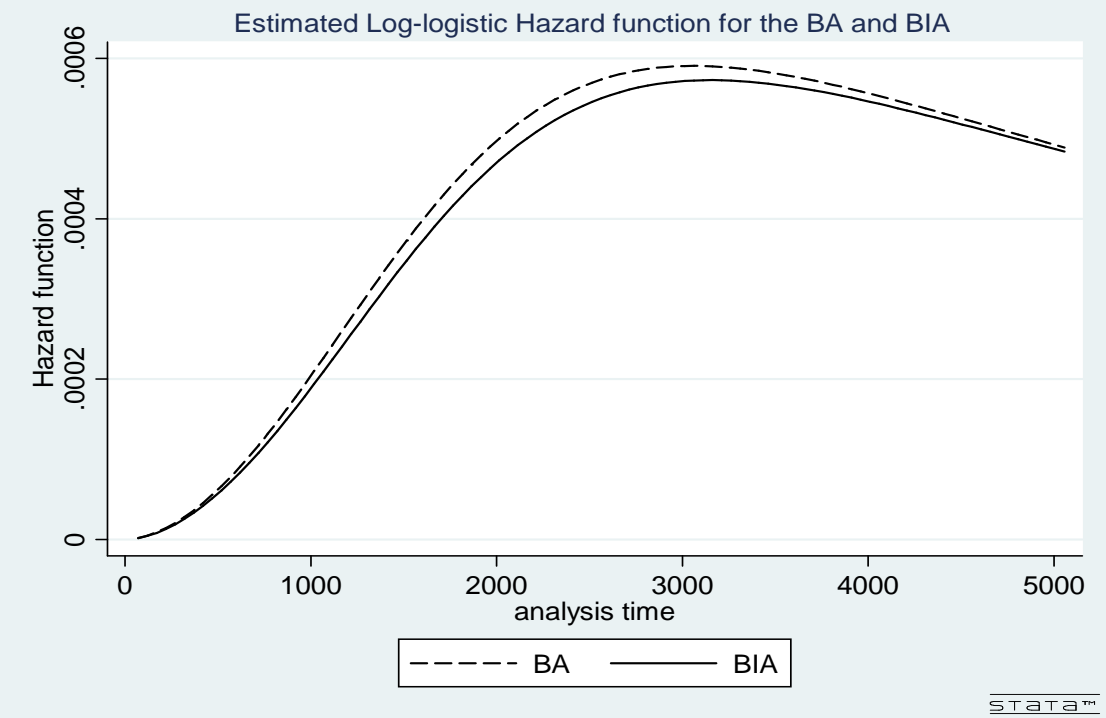

